\title{
M. N. Roy and the Frankfurt School: Socialist Humanism and the Critical Analysis of Communication, Culture, Technology, Fascism and Nationalism
}

\section{Christian Fuchs}

\author{
University of Westminster, London, UK, http://fuchs.uti.at, @fuchschristian
}

\begin{abstract}
Manabendra Nath Roy (1887-1954) was the founder of the Communist Parties of Mexico and India and a socialist-humanist philosopher. In the Western world, his works are today widely ignored and forgotten. This article introduces some philosophical aspects of Roy's thought. It engages with foundations of his theory and shows its relevance for the study of communication, culture, technology, the human being, fascism, and nationalism. Frankfurt School thinkers such as Theodor W. Adorno, Max Horkheimer, Herbert Marcuse, and Erich Fromm were interested in similar topics to Roy. This article also compares the approach of Roy and the Frankfurt School. It shows parallels between Roy and the first generation of the Frankfurt School with respect to themes such as the dialectic of technology and society, the dialectic of the Enlightenment, fascism, nationalism, and authoritarianism. In the age of new nationalisms and authoritarian capitalism, global environmental crises, capitalist crisis, and the digital crisis, socialist-humanist theories such as M. N. Roy's can inspire struggles for a humanist and socialist society as antidotes to the acceleration and deepening of the three crises.
\end{abstract}

Keywords: M. N. Roy, Manabendra Nath Roy, socialist humanism, Marxist humanism, Karl Marx, Marxism, communication, culture, technology, ideology, fascism, nationalism, authoritarianism, liberalism, capitalism, socialism, Frankfurt School, Theodor W. Adorno, Max Horkheimer, Herbert Marcuse, Erich Fromm, Georg Lukács, Rosa Luxemburg, Eric J. Hobsbawm, August Thalheimer

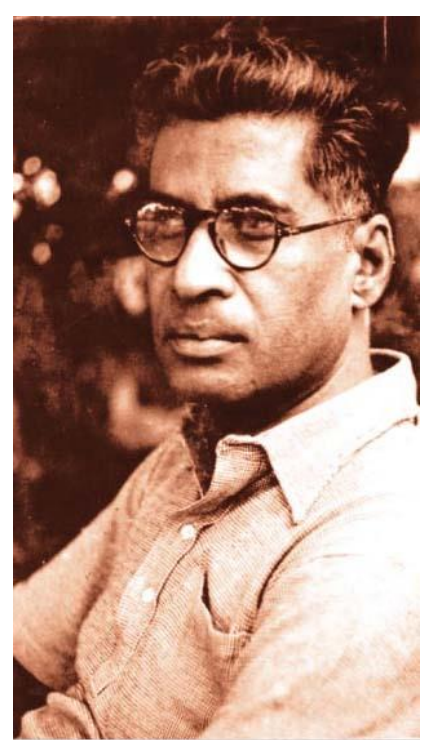

Image source: http://en.wikipedia.org/wiki/File:Mn roy2.jpg [Public domain] 


\section{Introduction}

This article asks: How can M. N. Roy's radical Marxist humanism inform the critical study of communication, culture, technology, the human being, fascism, and nationalism? What commonalities are there between Roy's approach and Frankfurt School critical theory?

Manabendra Nath (M. N.) Roy (1887-1954) was a Marxist-humanist thinker and politician. As a humanist he opposed Stalinism, Gandhism and the Indian National Congress' and its leader Subhas Chandra Bose's political position towards Hitler and the Nazis, which placed him outside the mainstream of both the communist and the anti-colonial movements, contributing to "the forgetting of M. N. Roy" and his being "lost to the historical record" (Manjapra 2010, xiv). He experienced turmoil, wars and transitions in the $20^{\text {th }}$ century and was a contemporary of Frankfurt School thinkers such as Theodor W. Adorno, Max Horkheimer, and Herbert Marcuse. Coming from India and spending sixteen years (1915-1931) in countries such as the USA, Mexico, Germany, Uzbekistan, France, Luxembourg, and China (see Ray 2016a), he experienced capitalism and colonialism in various parts of the world.

Both Roy and the Frankfurt School were inspired by Marx and humanism and were interested in topics such as the human being, technology, culture, communication, ideology, liberalism, fascism, authoritarianism, and nationalism. Roy wrote his book Revolution and Counter-Revolution in China in the late 1920s while connected to the Frankfurt Institute for School Research (Manjapra 2010, xiii, 70, 84, 91 [footnote 27]). In Germany, Roy and August Thalheimer became close friends and the former conversed in communist circles with the likes of Karl Korsch, Georg Lukács, Eduard Fuchs, Willi Münzberg, Franz Mehring, and Felix Weil (Manjapra 2010, 39-40; 67-70). The latter funded the founding of the Institute for Social Research.

Subhrajit Bhattacharya $(2016,1432)$ points out that Roy and Horkheimer at the same time in the 1930s "sought to understand the regression of 'civilisation' in the light of philosophy, one in an Indian prison, another in his exile years in America". Both Roy and the Frankfurt School took a critical interdisciplinary approach that combined political economy, philosophy, sociology, psychoanalysis, and cultural criticism. It is interesting to compare the approaches of Roy and the first generation of the Frankfurt School respecting the themes of the human being, technology, culture/communication, ideology, liberalism, fascism, authoritarianism, and nationalism.

As an introduction, some aspects of Roy's biography will now be discussed (for details see Manjapra 2010; Roy S. 1997; Tarkunde 1982).

Roy came from a Brahmin family in Bengal. He became a "full-blooded [Indian] nationalist" (Roy 1942, iii) who was convinced that Indian culture was superior to Western culture and determined to organise an armed revolution against the British rule of India. Observers identify three stages in Roy's political development: He "started as an ardent nationalist, became an equally ardent communist and ended as a creatively active Radical Humanist" (Tarkunde 1982, v).

After the first phase in his political development Roy, in the second stage, became a communist when he went abroad during the First World War. Roy was a founder of the Mexican Communist Party in 1917 and the Communist Party of India in the 1920s. While staying abroad in the USA and Mexico he gave up the belief that there was a progressive element in nationalism and embraced aspects of Western culture (Roy S. 1987, 1-13). In the 1920s, he was a member of the Communist International (Comintern)'s Presidium. 
At the Second Congress of the Comintern in 1920, Lenin (1920) presented Theses on the National and Colonial Questions. Lenin argued that the "entire [communist] policy on the national and the colonial questions should rest primarily on a closer union of the proletarians and the working masses of all nations and countries for a joint revolutionary struggle to overthrow the landowners and the bourgeoisie" (1920, 146). Roy (1920) presented Supplementary Theses on the National and Colonial Question that were more detailed than Lenin's theses and resulted in Lenin's taking up and agreeing with Roy's inputs. In his theses, Roy (1920) argued that European capitalism "depends on control of extensive colonial markets and a broad field of opportunities for exploitation" in order to counter overproduction, that the "super-profits made in the colonies form one of the main sources of the resources of contemporary capitalism", and that therefore the "Communist International must enter into much closer connection with the revolutionary forces that are at present participating in the overthrow of imperialism in the politically and economically oppressed countries".

Roy was expelled from the Comintern in 1929. He was close to Bukharin, whom Stalin wanted to get rid of, and supported anti-Stalinist Marxist movements such as the Communist Party of Germany (Opposition) (KPO), whose leader August Thalheimer was Roy's friend and ally. Both Thalheimer and Roy were part of the International Communist Opposition. Communists around Thalheimer and Heinrich Brandler opposed the Stalinist position that the social democrats were the main enemy of the working class. Stalinists described social democrats as "social fascists", and did not focus enough on the critique of Nazi-fascism. Members of the Communist opposition movement such as Thalheimer argued for a united front of social democrats and communists against Nazi-fascism. Roy wrote for the KPO's publications and found the notion of the united front of the exploited and oppressed feasible for struggles in the colonies (see Roy 1929a; 1929b). In the late 1920s, Stalin and his followers in the Comintern such as Otto Wille Kuusinen disagreed with Roy's assessment that the "nationalist bourgeoisie" in the colonies was compromising with imperialism but rather claimed that "the Indian bourgeoisie was brutally suppressed by Imperialism" (Roy 1943, 4849).

Consequently, Stalinists started to oppose Roy, which resulted in his expulsion from the Comintern (see Ray 2016b). The Stalinists accused the likes of Thalheimer, Brandler, and Roy of "Luxemburgism" (Manjapra 2010, 43-44; 70-71; 86-87), which, given Rosa Luxemburg's fusion of socialism, Marxism, and humanism, Roy and his comrades did not take as an insult but as confirmation that they were true communists. Roy $(1943,47)$ argues that the Communist International's failed assumption that "Social Democracy was a greater enemy of revolution than Fascism" resulted in the Comintern helping "Fascism to capture power in Germany". Roy argues that it was a grave mistake that Soviet Minister of Foreign Affairs Molotov "held British Imperialism responsible for the war and thus, by implication, exonerated Fascism" (Roy 1943, 59-60).

Orthodox Marxists have characterised socialism as the ideology of the working class, which implies the need for dictatorship. They forgot that for Marx the interest of the working class "coincided with the interest of the entire society" (Roy 1943, 72), which is why socialism and Marxism are "the philosophy of the progressive mankind. The world can be reconstructed as a home of freedom and culture only along the lines indicated by Marxism. Therefore, Communism has come to its own. It has become the future of mankind, its heritage" (73). For Roy, the Soviet system wasn't communist. He argued that a true form of communism as radical-democratic humanism remains the important political goal and interest of humanity. 
In his third, humanist phase, Roy combined Marxism and humanism. In the 1930s, he joined the Congress Party, where he was active in the socialist faction. He broke with Congress during World World II over the question of how the party should position itself towards Nazi-fascism and the Allied powers. Roy argued that fascism was the world's greatest danger and for the support of the Allies. Others in Congress, such as Gandhi, said that there should only be support on the condition of Indian independence. Gandhi saw Roy as his "enemy number one" (Roy S. 1987, 17), while Roy characterised Gandhi as "the patron saint of [Indian] nationalism" (Roy S. 1987, 67; Roy 1968, 29).

In 1932, Roy was sentenced to twelve years in prison for having conspired to deprive the King Emperor of his sovereignty in India in the 1920s. The time he served was reduced; he was released in late 1936. He was a vocal critic and opponent of Italian and German fascism. Roy founded the League of Radical Congressmen in 1938, the Radical Democratic Party in 1940, and the Radical Humanist Movement in 1948. The Radical Humanist Movement in 1952, together with other humanist movements, founded the International Humanist and Ethical Union that is today known as Humanists International.

Whereas Roy during his communist phase argued for "[r]evolutionary nationalism" (1922, 177), which he distinguished from "reactionary nationalism" (1922, 166, 216; see the same phrases in Roy 1923, 42, 44), during his humanist phase he opposed "capitalist as well as socialist Nationalism" (Roy 1960/1947, 102) and argued that any nationalism is "a totalitarian cult" $(1960 / 1947,84)$ that needs to be replaced by the universal "brotherhood of free individuals" (1960/1947, 102) and the "cosmopolitan commonwealth of free men and women" that is " not compatible with the continuation of National States" (Roy 1953, 35).

Although some attention has been given to Roy's work in India, his philosophy and theory is widely forgotten. Roy's magnum opus Reason, Romanticism and Revolution, which has a great deal in common with Horkheimer and Adorno's Dialectic of Enlightenment, is a forgotten and undiscovered work. In September 2019, Roy's main book that was published in two volumes in 1952 (volume 1) and 1955 (volume 2) had just 23 citations on Google Scholar ${ }^{1}$. One of the purposes of this article is therefore to point critical scholars in the social sciences, humanities, communication and cultural studies towards Roy's works by introducing some of its important aspects.

In order to answer the research question that this article poses, it discusses four aspects of Roy's works and assesses their relevance for a critical theory of communication and culture. These themes are humanism (Section 2), technology (Section 3), culture and communication (Section 4), and ideology (Section 5). Section 6 draws some conclusions.

\section{Humanism}

Roy was both a humanist and a Marxist. He understood humanism as a romantic movement (Section 2.1) and engaged with Marx's works in the context of humanism (Section 2.2).

\subsection{Humanism as Romanticism}

Roy was a radical humanist and humanist Marxist. Humanism stresses the importance of the capacity of humans to change society. It is based on the insight that "man is the maker of his world" (Roy 1953, 47) and the assumption that the human being is "the archetype of society" (Roy 1960/1947, 94). Marx

\footnotetext{
${ }^{1}$ Data source: https://scholar.google.com/, accessed on 12 September 2019.
} 
was a passionate Humanist; and, with a burning faith in revolution, he was also a romanticist. The idea of revolution is a romantic idea, because it presupposes man's power to remake the world in which he lives. If purposeful human effort is left out of account, social development becomes a mechanistic evolutionary process, making no room for sudden great changes and occasionally accelerated tempo. As the prophet of revolution, Marx was a romanticist. He proclaimed his faith in the creativeness of man which, accelerating the process of social evolution, brought about revolutions. Marx being a Humanist, the force of his theory of revolution was its powerful moral appeal (Roy 1953, 17).

For Roy, humanism is built on the insight that the human being "is essentially rational and therefore moral. Morality emanates from the rational desire for harmonious and mutually beneficial social relations" (Roy 1953, 33). Radical humanism "thinks in terms neither of nation nor of class" (1953, 34), but in terms of the human being. Roy foregrounds the role of human activity in society: history "is the record of man's struggle for freedom" $(1989,4)$. For Roy, romanticism means the "passionate belief in the creativeness and freedom of man. [...] The idea of revolution, therefore, is a romantic idea. [...] The difference between reason and romanticism is that one perceives what is necessary and therefore possible, whereas the other declares impetuously what is desirable, what should be done" $(1989,11)$.

In society, the human being "is the measure of everything", which implies that "the merit of any pattern of social organisation or political institution is to be judged by the actual measure of freedom it gives to the individual" (Roy 1953, 38). Comparable to Marx, Roy argues that co-operation is the essence of society (Roy 1953, 38). Marx adds that co-operation is a social production process and a work process, which is why the economy is of particular importance in society (see Fuchs 2020a). Roy (1953) says that the experience of conflict results in the alienation of humans from co-operation and a loss of faith of humans in themselves (91) that means a "crisis of the soul of man" so that "man has forgotten what he is" (91).

A free humanist society requires the realisation of the co-operative essence of society: "Freedom is the progressive elimination of all the factors - physical, social, psychological which obstruct the unfolding of man's rational, moral and creative potentialities. The function of social relationships should be to secure for individuals, as individuals, the maximum measure of freedom" (Roy 1953, 38). For Roy, freedom

is the supreme value of life, because the urge for freedom is the essence of human existence. [...] [The human being's] urge for freedom [...] is undying, eternal. He may not be always conscious of it; often he is not. Nevertheless, it is the basic incentive for him to acquire knowledge and conquer environments by knowing them (Roy 1989, 496-497).

In his main philosophical work Reason, Romanticism and Revolution, published in two volumes in 1952 and 1955, Roy (1989) describes the history of how humanism, rationality, science, philosophy, art, education, and technology have since the time of the Renaissance challenged religious and supernatural authority and the struggles and contradictions involved in this development. Roy argues that modern science and philosophy were not created by the bourgeoisie, but that later the bourgeoisie "patronised them because they served their purpose" $(1989,46)$. He stresses that Arab philosophy was important for rescuing reason and the thought of ancient Greece while Europe was stuck in the Middle Ages $(1989,41)$. Arab thought "ultimately reached Europe to stimulate the age-long struggle for spiritual freedom and search for truth" so that the 
"examination of social political freedom - modern civilisation - resulted from that struggle" (1989, 74). Roy $(1989,42,68-69,74,128,314)$ especially foregrounds the importance of Averroes (1126-1198) and Avicenna (980-1037), who built on Aristotle to establish a rationalist and materialist philosophy.

Roy's stress on Averroes and Avicenna is comparable to the work of Ernst Bloch (2019), who in his book Avicenna and the Aristotelean Left stresses the importance of Avicenna and Averroes who "embraced transformation" (67) and advanced a "speculative materialism" (67). Whereas the Right Aristotelians believe in supernatural powers that kept humans from struggling for liberation, Left Aristotelians struggle for humanism.

Humanism is internationalist and cosmopolitan; it wants to organise society as a "cosmopolitan commonwealth of free men and women" combined with "a spiritual community, not limited by the boundaries of National States - capitalist, fascist, communist or of any other kind - which will gradually disappear under the impact of cosmopolitan Humanism" (Roy 1953, 35).

A radical humanist society includes cultural democracy: "Its culture will be based on universal dissemination of knowledge and incentive to scientific and all other kinds of creative activity" (Roy 1953, 46). Roy argues that

side by side with the efforts to change economic conditions, efforts should be made to create a cultural atmosphere in which the value of freedom will be appreciated by a larger and larger number of people, an atmosphere in which it will be possible to make more and more people feel the urge for freedom, feel that they are human beings and as such capable of experiencing freedom, here and now (1950a, 188-189).

Freedom requires "economic betterment and [democratic] political institutions" (1950a, 191 ) as well as a culture of "freedom of thought and judgment" and the advancement of "the spirit of enquiry and the ability to distinguish between right and wrong" (190).

Roy opposes both economic and political forms of dictatorship. He argues for economic, political and cultural democracy: "According to Marx, under Socialism, human reason will overcome irrational forces which now tyrannise the life of man" $(1953,18)$. Roy argues for a radical humanist society that is a grassroots democracy based on people's committees in politics and co-operatives in the economy. In such a society, local democracy is strengthened $(1953,43)$. Such committees are also "the school for the political and civic education of the citizen" $(1953,36)$. For Roy $(1989,474)$, humanist democracy is "a network of local political schools": "Every citizen will be informed and consulted for his opinion about the affairs of the state, that is, the political administration of his society" (Roy 1949, 939).

The humanist economy produces for human needs (Roy 1953, 46). It consists of

a network of consumers' and producers' co-operatives, and the economic activities of the society shall be conducted and co-ordinated by the people through these institutions. The co-operative economy shall take full advantage of modern science and technology and effect equitable distribution of social surplus through universal social utility services (Roy 1953, 69).

A radical humanist democracy is based on "People's Committees as the primary constituents of the democratic State, and co-operatives as the primary units of the cooperative Commonwealth" $(1953,70)$ : "Economic democracy is no more possible in 
the absence of political democracy than the latter is in the absence of the former" (1989, 472).

Roy (1989, 355-358) argues that Kant's (1724-1804) idealism is based on a dualism of ideas and the thing-in-itself, subject and object, noumenon and phenomena, appearance and reality, science and philosophy, and nature and mind; and that it therefore developed a dogmatic ethics that together with the approaches of Herder (17441803), Fichte (1762-1814), and Lessing (1729-1781) advanced German nationalism. Roy (1989, Chapter XVIII) writes that Hegel's (1770-1831) dialectical philosophy overcame Kant's dualism, stressing the creativity of the human mind and therefore humanism.

Roy points out that Marx has an "outstanding place in the history of philosophy" because his "materialist monism" questions the dualism of mind and matter by seeing matter "as the ultimate reality capable of producing life" $(1989,417)$. Roy again and again discusses the relationship of Marx and humanism.

\subsection{Marx and Humanism}

Roy (1989) argues that Marx's "view of history and social evolution was essentially teleologically fatalistic" (390). This view is disproved by Marx's famous formulation from The Eighteenth Brumaire of Louis Bonaparte that humans "make their own history, but they do not make it as they please; they do not make it under circumstances chosen by themselves, but under circumstances directly encountered, given and transmitted from the past" $(1852,103)$. History is conditioned by society's contradictions so that social struggles and human practices are the sources of a freedom that goes beyond and liberates humans from necessity. History is based on a dialectic of structuration and collective agency/struggles.

Roy contradicts his own claim that Marx was a historical fatalist when appreciating Marx's stress on agency and revolution: "The romantic view of life [...] leads to the liberating doctrine that man is the maker of the world, developed during a whole period of history from Vico to Marx. [...] Marxism is an attempted synthesis between the two apparently antithetical views of life - the rationalist and the romantic" $(1989,12)$.

Roy (1989) argues that the dialectic is for Marx a rational, scientific law, "Hegelianism applied to human history" (408), and that he combined rationalist dialectics with a romanticist theory of revolution $(409-410 ; 412)$ so that history is for Marx a "contradiction between rationalism and the romantic notion of revolution" (411). Because of his "emphasis on human action" (412) and his "burning faith in revolution" (420), "Marx was a Humanist, and as such a romanticist" (411). Marx's philosophy is a "synthesis of rationalism and romanticism" (413). Roy states that "Marx being a humanist, the force of his theory of revolution was its moral appeal. [...] In the last analysis, Capital is a treatise on social ethics - a powerful protest against the servitude of the toiling majority" (420).

Roy argues that Marxism needs to be freed from "the fallacy of economic determinism", which makes it consistent with "Radical Humanism" (421). In the last instance, Roy greatly appreciates Marx as a humanist and revolutionary theorist. But he misinterprets Hegelian dialectics. Dialectics does not just operate at the level of objective contradictions but also at the level of human practices. There is a dialectic of the subjective dialectic and the objective dialectic. And for Marx, class struggle is the subjective dimension of history because the exploited class thereby questions the class relation, by which it is compelled to produce surplus-value that it does not own, and class society. Class struggle as the making and unmaking of class relations between the exploited and the exploited is the subjective dimension of history. 
Marx's quote from the Eighteenth Brumaire does not have, as Roy assumes, a romantic-revolutionary side (humans make their own history) and a dialectical side (they do so under the dialectical contradictions of class society). It does not combine a nondialectical and a dialectical aspect of society but expresses society's meta-dialectic of the objective dialectic and the subjective dialectic. Both dimensions of history are dialectical. We cannot say therefore, as Roy $(1989,491)$ does, that the "fiery prophet of social justice in Marx was more a Humanist than a Hegelian". Rather, Marx's dialectic is humanist and his humanism dialectical. The problem of economic determinism and breakdown theory is not immanent in Marx's application and development of Hegelian dialectics but was the result of, on the one hand, the Bernstein-tradition of social democratic revision of Marx's theory and, on the other hand, the Stalinist tradition of the vulgarisation of Marx.

Roy says that Marx's insight in the sixth Feuerbach thesis that the individual and the human being's essence are "the ensemble of the social relations" (Marx 1845, 7) was "a great advance in the struggle for freedom" (Roy 1989, 392). Roy claims that Marx ignores that the activities of individuals constitute society $(1989,392)$. He says Marx omits "mental activity" and "conceptual thought" in society and social evolution (393) and "the human nature which underlies the ensemble of social relations" (395). He writes that by neglecting human nature Marx does not recognise "permanent values" that enable ethics (396). Roy (1989, Chapter IX) here limits his discussion to the German Ideology and ignores other works of Marx. In Capital, Marx stresses how conceptual thought, mental activities and human will guide human work:

what distinguishes the worst architect from the best of bees is that the architect builds the cell in his mind before he constructs it in wax. At the end of every labour process, a result emerges which had already been conceived by the worker at the beginning, hence already existed ideally. Man not only effects a change of form in the materials of nature; he also realizes [verwirklicht] his own purpose in those materials. And this is a purpose he is conscious of, it determines the mode of his activity with the rigidity of a law, and he must subordinate his will to it (Marx 1867, 284).

Roy did not focus on Marx's Economic and Philosophic Manuscripts where Marx identifies a dialectic of the individual and social structures as the foundation of society:

just as society itself produces man as man, so is society produced by him [...] Social activity and social enjoyment exist by no means only in the form of some directly communal activity and directly communal enjoyment [...] that which I make of myself, I make of myself for society and with the consciousness of myself as a social being. [...] Above all we must avoid postulating "society" again as an abstraction vis-à-vis the individual. The individual is the social being. [...] Man's individual and species-life are not different, however much - and this is inevitable - the mode of existence of the individual is a more particular or more general mode of the life of the species, or the life of the species is a more particular or more general individual life (Marx 1844, 298-299, emphasis in original).

In the German Ideology, the Marxian work Roy (1989, Chapter XIX) is referencing in his discussion, Marx says that the starting point of the analysis of society is "the existence of living human individuals" (Marx and Engels 1845-1846, 31). It is not true that Marx does not assume there is no human nature. His whole concept of alienation is 
based on the notion of human essence. In the Economic and Philosophic Manuscripts, Marx (1844) points out that the human being is in essence a natural, social, objectivesubjective, conscious, self-conscious, sensual, thinking, active, creative, language-using, working being. He also bases a critical humanist ethics on this notion of human essence that advances the insight that class society alienates humans, cripples human nature, and is therefore incompletely human and incompletely social. As a consequence, communism is "practical humanism" and "humanism mediated with itself through the supersession of private property" (Marx 1844, 341).

Written in 1844, the Economic and Philosophic Manuscripts were first published in the original German in 1932. Martin Milligan created the first English translation, published in 1959. Roy died in 1954 and was not fluent in German, which means that he could not read the Manuscripts. If he had, his judgement of Marx might have been somewhat different. His criticism of Marx can also be read as a self-criticism of his own earlier phase where he relied much more on determinism and economism than in his later stage. Above all, Roy's critique should not be seen as relating to Marx, but to the Stalinists that he opposed by the humanist stress on human agency and democratic socialism.

Since the start of a new world economic crisis in 2008, we have experienced not just a brief spring of progressive movements but also the rise and spread of new nationalisms, new authoritarianisms, and new fascism (Fuchs 2018; 2020b). Once again, "[b]ourgeois society stands at the crossroads, either transition to socialism or regression into barbarism" (Luxemburg 1916, 388). Engaging and updating the works of humanist socialists such as Roy, Ernst Bloch, Raya Dunayevskaya, Erich Fromm, Lucien Goldmann, C.L.R. James, Henri Lefebvre, Rosa Luxemburg, Herbert Marcuse, Karl Marx, E. P. Thompson, Raymond Williams, and so on, reminds us that democratic socialism is the strongest weapon against fascism, nationalism, and war.

Humanism shaped how Roy saw various aspects of society, such as technology. The next section discusses his view of the relationship between technology and society.

\section{Technology}

Roy was a critic of technology as a means of exploitation and domination, but favoured an alternative, non-capitalist modernity that involves a humanist use of technology. Roy differed in this respect from Gandhi (Section 3.1). He provides a dialectical analysis of technology (Section 3.2).

\subsection{Roy and Gandhi}

We have already mentioned in the introduction of this article that there was no love lost between Roy and Gandhi. Roy questions the identity of anti-imperialism and nationalism (Roy 1942, 3). He says that the disappearance of British imperialism is a precondition for freedom in India, but that this disappearance will not "necessarily mean freedom for India" $(1942,3)$. He sees nationalism as an unnecessary and dangerous feature of certain anti-imperialist movements, and as having fascist potentials. In the context of India and the Second World War, Roy was particularly critical of "the fact [...] that the sympathies of the average Indian nationalist are all on the side of the Fascist Powers" $(1942,14)$. Roy believed that the support of the Nazi-fascists by Indians who hated British imperialism would not result in the end of imperialism but in the rise of fascism in India. He opposed any form of nationalism and argued that with the advent of Gandhi's influence, "authoritarianism became the fundamental principle of Indian Nationalism", because Gandhi "demanded submission to a spiritual authority" (Roy 
2006/1945, 12): "Gandhism is the accepted ideology of Indian Nationalism" $(2006 / 1945,26)$.

Roy argues that Indian nationalists "reject precisely what is 'good' in capitalist civilisation", namely "the tremendous advance of science, in theory and practice" (1950b, 109). Gandhism's focus on "non-violence, poverty, continence" (1960/1947, 19), and "[p]uritanism" $(1960 / 1947,20)$ inspires "the capitalist and his employees to work hard and spend little, thus making possible the accumulation of capital", which is why "the Mahatma's teaching has acquired great prestige among the capitalists of India" (1960/1947, 20).

Gandhi had a particular view of what role technologies should play in society. He was critical of industrialisation and modern technologies because he saw them as disruptors of traditional life. Gandhi says in this context:

I don't believe that industrialization is necessary in any case for any country. It is much less so for India, Indeed I believe that independent India can only discharge her duty towards a groaning world by adopting a simple but ennobled life by developing her thousands of cottages and living at peace with the world. High thinking is inconsistent with a complicated material life, based on high speed imposed on us by Mammon worship. All the graces of life are possible, only when we learn the art of living nobly (Gandhi, in Tendulkar 1953, 224-225).

Gandhi sees machinery as the cause of imperialism, or what he terms the exploitation of one nation by another:

What is the cause of the present chaos? It is exploitation, I will not say, of the weaker nations by the stronger, but of sister nations by sister nations. And my fundamental objection to machinery rests on the fact that it is machinery that has enabled these nations to exploit others (Gandhi, in Bose 1948, 64-65).

These quotes show that Gandhi equates and conflates modern technology and industry on the one side with capitalism and imperialism on the other side. He does not see the possibility of an alternative, socialist modernisation. He furthermore sees technology as the cause of exploitation. This position is different from techno-optimist determinists such as Marshall McLuhan who see modern technologies as the enablers and causes of a better future. Gandhi is a representative of pessimistic technological determinism that assumes that modern technologies with necessity call forth and are the cause of negative features of society such as commodification and exploitation. Both optimistic and pessimistic technological determinism share the short-sighted assumption that it is technology that determines society. They disregard how society shapes the character and use of technology and that the relationship of technology and society is dialectical and therefore full of contradictions.

Gandhi favoured the widespread use of manual technologies, especially the spinning-wheel and the handloom. He argued that "[r]estoration [...] of the spinning-wheel solves the economic problem of India at a stroke" $(1997,165)$ : "When as a nation we adopt the spinning-wheel, we not only solve the question of unemployment but we declare that we have no intention of exploiting any nation, and we also end exploitation of the poor by the rich" $(1997,167)$. Gandhi saw the spinning wheel as "the panacea for the growing pauperism of India" $(1983 / 1948,441)$. His view of technology is antimodern and focused on preserving and advancing manual labour and thereby toil. Gandhi's view of manual technologies is, just like his view of modern technologies, 
techno-deterministic. He assumes that the spinning wheel and the handloom result in a society without poverty.

Gandhi overlooks that technology is "being looked for and developed with certain purposes and practices already in mind" (Williams 2003/1974, 7). As Williams states: "Technological determinism is an untenable notion because it substitutes for real social, political and economic intention" (2003/1974, 133). The impacts of technology on society are shaped by interests and contradictions in society. In capitalism, there certainly is an "interlock of military, political and commercial intentions" at play in the design and use of science and technology (Williams 2003/1974, 137). But there is also the potential for shaping science and modern technology by democratic interests (Williams 2003/1974, 146).

Roy (1950b, 124) does not just criticise that Gandhi and his followers want an "ethical capitalism", which means that they overlook how capitalist interests shape science and technology and call forth negative consequences; he also argues that the "core of Gandhism [...] is its hostility to industrialism and the modern world" (1960/1947, 18). For Roy, Gandhi's preaching of the abstention from the use of technology and a simple rural life is an ideology that celebrates poverty and thereby supports the profit interests of capitalist organisations: "The spiritualist doctrine of self-control, simple living, voluntary poverty, fits in with the requirements of unsocial capitalism" (1950b, 236).

Roy argues that there is a dialectic of technology and society.

\subsection{The Dialectic of Modern Technology and Society}

Roy shared concerns about modern technology but rejected technological determinism. He argued that technology should be seen in the context of society and therefore has potentials to advance both slavery and freedom:

the emphasis on freedom at this time is called for by a material factor, namely, modern technology. There is a very wide-spread fear that this immense development of technology will bring slavery for mankind, and the fear is not unreasonable. The Nazis were only a little ahead of their time when they tried to set up a single world tyranny, and if such a tyranny is ever established it will be almost impossible to overthrow. Thus this great development of technology puts the problem before us in the form of a choice: world slavery or world freedom (Roy 1960/1947, 12).

Roy sees modern technology as standing in a dialectical relationship to society, which means that technology has certain unpredictable dynamics, but is shaped by humans' interests, which means that in principle humans can by practicing overcoming domination and exploitation also shape and create technologies that advance freedom, equality and democracy. Roy argued for the creation of humanist technologies as part of the struggle for a humanist society. "Machine should not be the Frankenstein of modem civilisation. Created by men, it must subserve man's purpose - contribute to his freedom" (Roy 1953, 40). He writes that there can be no freedom without humanistic modern technology:

Technology is capable, in principle, of providing an enjoyable life for all, and there is no good reason why life should not be enjoyed [...] Freedom, equality and democracy are impossible if you reject modern technology (Roy 1960/1947, 21). 
Progressive satisfaction of material necessities is the precondition for the individual members of society unfolding their intellectual and other liner human attributes. An economic reorganisation such as will guarantee a progressively rising standard of living will be the foundation of the Radical Democratic State (Roy 1953, 46).

While Gandhi was an anti-modernist, Roy argued for an alternative modernity, a socialist-humanist modernity that shapes, creates and uses technologies in manners that abolish toil and advance freedom, democracy and sustainability:

Science not only enables man to conquer nature, but also helps him to understand nature, his relation with it and with other human beings who are integral parts of nature. [...] Modern technological trends threaten to offer mankind at the altar of the Moloch, and create a Frankenstein lusting to devour its creator, because the practical, utilitarian value of scientific knowledge has been allowed to eclipse its ideal value (Roy 1947a, iii).

There are strong parallels between Roy's and Herbert Marcuse's analysis of modern technology. Like Roy, Marcuse rejects anti-technological ideology that celebrates toil: "The enemies of technics readily join forces with a terroristic technocracy. The philosophy of the simple life, the struggle against big cities and their culture frequently serves to teach men distrust of the potential instruments that could liberate them" (Marcuse 1998/1941, 63).

Marcuse, just like Roy, identifies both emancipatory and repressive potentials of modern technology and argues that the actual character and impact of technology depends on broader societal contexts, interests and struggles: "Technics by itself can promote authoritarianism as well as liberty, scarcity as well as abundance, the extension as well as the abolition of toil" (Marcuse 1998/1941, 41). Marx and Roy base their analysis on Marx' Hegelian analysis of technology that stresses that there is an antagonism between the essence of modern technology and the actual impacts of technology under capitalist conditions. Marx, for example, argues that

machinery in itself shortens the hours of labour, but when employed by capital it lengthens them; since in itself it lightens labour, but when employed by capital it heightens its intensity; since in itself it is a victory of man over the forces of nature but in the hands of capital it makes man the slave of those forces; since in itself it increases the wealth of the producers, but in the hands of capital it makes them into paupers (Marx 1867, 568-569).

Marcuse, like Roy, argues for a socialist modernity where technology is shaped and used in manners that overcome toil and advance freedom and technology is governed in a democratic manner:

If everyone has become a potential member of the public bureaucracy [...], society will have passed from the stage of hierarchical bureaucratization to the stage of technical self-administration. [...] We have pointed to the possible democratization of functions which technics may promote and which may facilitate complete human development in all branches of work and administration. Moreover, mechanization and standardization may one day help to shift the center of gravity from the necessities of material production to the arena of free human realization. [...] 
Technological progress would make it possible to decrease the time and energy spent in the production of the necessities of life, and a gradual reduction of scarcity and abolition of competitive pursuits could permit the self to develop from its natural roots. The less time and energy man has to expend in maintaining his life and that of society, the greater the possibility that he can "individualize" the sphere of his human realization (Marcuse 1998/1941, 58-59; 63; 64).

In digital capitalism, we find both techno-optimism and techno-pessimism. In this context, the effects of Al-based automation is a heavily discussed topic.

The futurist Martin Ford (2015) warns in his book Rise of Robots: Technology and the Threat of a Jobless Future that Al-based automation "has a dark side of its own, and if it results in widespread unemployment or threatens the economic security of a large fraction of our population" $(2015,283)$. He writes that

factory jobs are disappearing across the globe at a rapid clip. Labor-intensive manufacturing as a path to prosperity may begin to evaporate for many developing nations. [...] The greatest risk is that we could face a 'perfect storm' - a situation where technological unemployment and environmental impact unfold roughly in parallel, reinforcing and perhaps even amplifying each other" (Ford 2015, 283; 284).

Accelerationists such as Srnicek and Williams (2015) and Bastani (2019), in contrast to Martin Ford, point out that Al-based automation should be entirely welcomed. Srnicek and Williams $(2015,179)$ say that "the automation of mundane labour" forms "the basis for a fully postcapitalist economy, enabling a shift away from scarcity, work and exploitation, and towards the full development of humanity".

Bastani (2019) argues that new technologies will result in a major disruption of society, creating "a world dramatically different from our own" (11): "the old world will transition to the new more quickly than many imagine" $(2019,77)$; and "within a generation we are set to reach peak human" $(2019,80)$, ushering in the emergence of fully-automated luxury communism, "a society in which work is eliminated, scarcity replaced by abundance and where labour and leisure blend into one another" $(2019,50)$. Williams and Srnicek (2013) state that "[w] want to accelerate the process of technological evolution. [...] the left must take advantage of every technological and scientific advance made possible by capitalist society. We declare that quantification is not an evil to be eliminated, but a tool to be used in the most effective manner possible".

Whereas accelerationists see Artificial Intelligence ushering in communism, neoliberals see it as a way of accelerating corporate profit-making. The conservative UK government argues in its Industrial Strategy that "[e]mbedding Al across the UK will create thousands of good quality jobs and drive economic growth" (Department for Business, Energy \& Industrial Strategy 2019).

While utopian communist optimism and neoliberal optimism expect changes from new technologies that they assess as positive (communism and capitalist growth respectively), pessimists argue that new technologies result in a rise of unemployment, precarity, inequalities, social problems, and so on. The basic problem of all of these approaches is that they do not see modern technology in modern society as a complex, contradictory system but rather inscribe certain societal changes into technology. The actual effects of society depend on the results of class and social struggles that shape the character and use of technology in society. 
In the next section, we will discuss aspects of Roy's works that have to do with culture and communication.

\section{Culture and Communication}

Roy developed a distinct form of cultural materialism as part of which he discussed the materialist character of society (Section 4.1) and the relationship of culture and the economy (Section 4.2). He had less to say on communication, but his analysis of culture can inform the critical analysis of communication (Section 4.3).

\subsection{Materialism and Society}

One basic question for any critical theory is how mind and matter as well as culture and economy are related. In Marxist theory, this question is known as the base/superstructure-problem.

For Roy, the entire world is material. Materialism is "the explanation of the world without the assumption of anything super-natural" (Roy 1940, 227). Matter is "a vibratory substance" (Roy 1947a, 86), "the sole existence" (1947a, 99), "the only reality" and "ontologically real" (1947a, 100). Roy argues that in society, both "ideal and physical" (1989, 8-9) realities are material, have "their respective dynamics or dialectics" and are "mutually influenced" (9). Roy advanced a materialist theory of knowledge. "Man's relation with nature has been from the very beginning not of passive contemplation, but of action" (Roy 1940, 249). Therefore, "knowledge is action, not passive contemplation" (249); "whatever is within the ken of human consciousness is material. Because, something immaterial (spiritual, in the traditional sense) can never be cognisable to human mind, itself a product of matter in a particular state of organisation" (251).

Roy's philosophy is monistic and materialist. He stresses that the non-human and the human world are material. For Roy, the human being is entirely material because the body and the mind are physical entities developed in the course of evolution. In the realm of humans and their societies, Roy stresses the dialectical interaction of ideas/physical reality, mind/body, nature/society, environment/individual, and economy/culture. All of these realms are expressions of matter as a dynamic, vibratory process. There are no ideas without the human mind's embeddedness into and interaction with the body and a natural and social environment.

Roy deals with the question of the means of production in society. He stresses that the brain is humanity's key means of production:

But may we not ask who created the first means of production? What was there originally? Did the first man appear with hammer and sickle in hand? No. But he did come into the world with another means of production, the most powerful ever created. And that was his brain [...] We are all born with it, and it remains our basic asset, provided that we can appreciate its worth and make proper use of it. If you prefer a crude hammer, or even an electric hammer, or something still better, the most modern technological inventions, to your brain, I wish you luck (Roy 1960/1947, 65-66).

The creation of the first extra-organic means of production was a deed done by an animal with highly developed brain, capable of thought. An idea preceded the creation of the first means of production (Roy 1960/1947, 93). 
The brain is a means of production, and produces the most revolutionary commodity (Roy 1953, 36).

Roy $(1989,17)$ stresses that conceptual thought is characteristic of humans. Conceptual thought is "thinking stimulated by mental images" $(1989,17)$. "Conceptual thought depends on language. So, it can be said that man is fully differentiated from his animal ancestry only when he coins words for expressing definite ideas" (17). Animals articulate sounds but this activity is entirely dependent on stimuli from their immediate environment; they lack conceptual thought (17). This means that humans have the capacity to anticipate and reflect on the consequences of their actions, select among different potential actions, make moral judgements that guide their actions, and discuss and communicate their feelings, actual and potential choices, interests, experiences, morals, and actions. Humans are rational, anticipatory, self-conscious, thinking, creative, moral, languaging, social, communicative, societal beings. Roy $(1989,479)$ argues that the human being is "a thinking animal". But humans are also social, communicative beings.

What needs to be added to Roy's approach is the crucial role of work and production in human existence (see Fuchs 2020a). Based on their capacities as rational, thinking, creative, social beings, humans engage in the social production of ideas, technologies that they use to transform the world, goods that satisfy human needs, collective decisions, worldviews, and culture. They together produce an economy, a political system, and culture, i.e. forms of sociality and social relations. Work is the process of social production through which humans create something new that satisfies their needs. Social production means that the economy and work are at the heart of all social realms, including the political and cultural life. At the same time, social systems go beyond mere production by having emergent qualities. Once humans produce structures, these structures have specific features and a particular logic that go beyond economic necessity and are shaped by human interests and their contradictions.

The dialectic of culture and the economy is based on social production, which means that the combination of the human capacities to produce and to be social are at the heart of all realms of society, including the economy and culture. Each social realm is based on social production that forms the material foundation of humans and society. Each social realm also has particular, emergent dynamics and contradictions that cannot be reduced to production. The capacity for social production is itself a combination of the capacity to form and communicate ideas and the capacity to experience, engage with and transform the environment, i.e. a dialectic of communication and work. Social production combines the work character of communication and the communicative character of work (Fuchs 2020a).

An important question for any theory of society is that of how culture and the economy are related.

\subsection{Culture and the Economy}

Roy challenges the assumption that culture and ideas are reducible to the economy and therefore derive from economic structures, i.e. productive forces and the relations of production. He stresses that culture has a particular logic that is based on and influences human experiences and events in society:

The logical development of ideas and the generation of new social forces take place simultaneously, together providing the motive force of history. But in no 
given period can they be causally connected except in the sense that action is always motivated by ideas" (Roy 1989, 10).

We do not accept the Marxist doctrine that moral values, cultural patterns, aesthetic tastes, are all ideological super-structures of economic relations [...] the so-called ideological super-structure is not hanging in the air; that it too has its own roots. Ideas, undoubtedly, are influenced by social experience, influencing, at the same time, social and historical events. But they have a logic and dynamics of their own (Roy 1960/1947, 70-71).

Ideation is a physiological process resulting from the awareness of environments. But once they are formed, ideas exist by themselves, governed by their own laws. [...] Cultural patterns and ethical values are not mere ideological super-structures of established economic relations. They are also historically determined - by the logic of the history of ideas $(1953,52)$.

For Roy, ideologies and ideas are "structures standing by themselves" and not superstructures $(1960 / 1947,71)$. Materialism means for Roy that the productive forces do not determine history because they are "the collective expression of the creativeness of man, and the creative man is always a thinking man" $(1989,8)$. This means that humans, because of their self-consciousness and "the creative role of intelligence" $(1989,8)$, have the capacity to make choices, to envision the future, to identify and act based on interests, and to organise and act collectively.

In his book Revolution and Counter-Revolution in China, Roy (1946/1930, 3; 6-7), following Plekhanov, argues that "social evolution" is determined by "the natural conditions and forces of production" (1946/1930,3). Roy therefore argues, for example, that in ancient China, the "evolution of private property [...] was caused by the development of the means of production", and that the "progressive perfection of tools in the hands of man - the development of the means of production - again is determined by physical conditions" $(1946 / 1930,17)$. The problem with this view is that technology, nature and work as aspects of the forces of production do not operate independently but within definite social relations between human beings. The views of Roy and Plekhanov disregard the relations of production and are therefore prone to a naturalistic and technological determinism. Roy's critique of economic determinism during his last, humanist phase of intellectual development was partly also self-criticism of his earlier thought.

Humanism is both a worldview and a political movement. Any movement has a worldview that guides and interacts with its practices. There is a dialectic of ideas and practices. The rise of various humanist movements is not reducible to the economic structure of feudalism but stands in the context of class and social struggles and therefore collective social practices. Humans who oppose a certain social order and organise themselves engage in collective practices and develop collective ideas that guide their collective struggle. Marx's father was a relatively well-situated lawyer. Engels' father owned large textile factories in Salford (UK) and Barmen (Prussia). Rosa Luxemburg's father was a timber trader. George Lukács' mother was the heir of a rich timber trading family and his father was a bank director. These examples show that the class and family backgrounds of those who engage in certain movements do not mechanically determine their political positions and the question of whether they join certain movements. That there is a relative autonomy of ideas so that ideas are socially produced and interact with economy and society means that political position and worldview cannot be read from and are not determined by class background. 
Marx points out that once a certain ideology becomes historically attached to a class, this class supports and creates individuals and groups who develop this ideology. He speaks of a "division of mental and material labour" (Marx and Engels 1845-1846, 60) in the ruling class: "inside this class one part appears as the thinkers of the class (its active, conceptive ideologists, who make the formation of the illusions of the class about itself their chief source of livelihood)" (Marx and Engels 1845-1846, 60). The

individuals composing the ruling class possess among other things consciousness, and therefore think. Insofar, therefore, as they rule as a class and determine the extent and compass of an historical epoch, it is self-evident that they do this in its whole range, hence among other things rule also as thinkers, as producers of ideas, and regulate the production and distribution of the ideas of their age: thus their ideas are the ruling ideas of the epoch (Marx and Engels 1845-1846, 59).

Given a division of labour in the ruling class, one cannot assume that capitalists directly determine the ideas disseminated with the help of books, public debates, business schools, the media, and so on. Intellectuals have their own logic and interests and in the first instance often strive to accumulate reputation and not monetary capital. With the help of funding, donations, consultancy, cultural networks, the support of think tanks, the ownership of media, etc., capital exerts indirect pressure on the realm of the production of ideology. At the same time, ideologues who strive for reputation are also keen on shaping the ideas of members of the ruling class and the political elite in order to increase their own reputation. Similar things can be said about the relationship of intellectuals and politicians who strive to accumulate power.

There is a complex relationship between ideologues, political actors and economic actors in capitalist society. They strive towards accumulating reputation (ideologues), power (political actors) and money capital (capitalists). Insofar as these logics coincide, they enter mutually beneficial relations that can develop their own contradictions and can therefore also break down.

In some, but certainly not all passages of his writings that focus on culture, it seems that Roy sees culture as almost independent from political economy, simply saying that his approach is materialist because everything including ideas is material. The consequence of such an assumption is a materialist dualism where the whole world is material, while within society there are independent material substances, namely culture and the economy. Culture cannot be reduced to political economy; however, it is also not fully independent but grounded in the economy, and at the same time relatively autonomous.

Roy $(1947 b, 898)$ argues that Marx's suggestion that being determines consciousness implies that "man's ideals are shaped by the tools with which he works". However, a mode of production does not only consist of the productive forces but also interacts with the relations of production. Marx suggests that consciousness is embedded into society's social relations because humans are ensembles of social relations, which means that technology is not, as assumed by technological determinism, the determining factor of society. Rather, social relations are the determining factor of culture, ideas, politics, and the economy, which means that society only exists in and through humans' social relations.

Marx argues that the mode of production is not simply the "physical existence of the individuals", but "a definite form of activity of these individuals" in which they express their lives (Marx and Engels 1845-1846, 31). It is "a definite mode of life" (Marx 
and Engels 1845-1846, 31): "The production of ideas, of conceptions, of consciousness, is at first directly interwoven with the material activity and the material intercourse of men - the language of real life" (36). Material production includes "[c]onceiving], thinking, the mental intercourse of men" (36), "mental production as expressed in the language of [...] politics, laws, morality, religion, metaphysics, etc." (36). This means that for Marx ideas are material entities and thinking is a material process. And the production of ideas is a social process. Culture as the production and circulation of ideas and meanings takes place within the ensemble of social relations that constitutes the human subject. Marx and Engels stress that ideas depend on the social relations of the humans who think, create, share, and reproduce them:

Ideas can never lead beyond an old world order but only beyond the ideas of the old world order. Ideas cannot carry out anything at all. In order to carry out ideas men are needed who can exert practical force (Marx and Engels 1845, 119).

Undeterred by this examination, the French Revolution gave rise to ideas which led beyond the ideas of the entire old world order (Marx and Engels 1845, 119).

In respect to Marx's (1845-1846) passages from the German Ideology mentioned in the preceding paragraph, Roy (1989, 393-394) argues that Marx does not see that consciousness is foundational for human activities. This assessment is flawed: Marx conceives of consciousness as material because the brain is a material system. And self-consciousness enables human freedom:

free, conscious activity is man's species-character. [...] Conscious life activity distinguishes man immediately from animal life activity. It is just because of this that he is a species-being. Or it is only because he is a species-being that he is a conscious being, i.e., that his own life is an object for him. Only because of that is his activity free activity. Estranged labour reverses this relationship, so that it is just because man is a conscious being that he makes his life activity, his essential being, a mere means to his existence (Marx 1844, 276).

The struggle against religious and monarchic authority has expressed itself not just in the realm of politics and the economy but also in realms such as philosophy, science, art, education, and literature, i.e. in cultural forms. The political-economic and the cultural movements and social forms that challenged the feudal social order that dominated the Dark Ages all shared certain goals and interests but did not originate from the same people and were not organised within one overall unified, consistent movement. The Enlightenment was a political-economic and cultural movement consisting of many strands that challenged the feudal system's economic, political, and cultural structures.

As one example for the relationship of ideas and the economy, Roy discusses the relationship of humanism and the bourgeoisie: "Renaissance Humanism was not the ideology of the rising bourgeoisie" $(1989,79)$. Humanism rather started and developed as a movement that challenged religious, monarchic, aristocratic, feudal authority and rule. It took on different forms, including liberalism, reactionary romanticism, socialism, and communism, which means that humanism is a contradictory movement.

Liberalism developed in the sixteenth century independently from the economy "according to the logic of the evolution of thought" $(1989,300)$. Later on, "a particular class" - the bourgeoisie - "accepted it" (300). Roy argues that given this sequence, 
liberalism is not "the ideology of the bourgeoisie" and the "philosophy of capitalism" (300, see also $303 ; 318)$. He writes that liberalism and capitalism developed simultaneously and concomitantly (302) and sees liberalism as going beyond economic philosophy and extending into politics and the ways of life (301-302). For Roy, the origin of liberalism is "the movement for the secularisation of politics" (303). He argues that liberalism did not originate as a capitalist project but was at a certain point of time adopted and shaped by the bourgeois class.

The classical liberal thinkers John Locke (1632-1704) and Thomas Hobbes (15881679) predominantly focused on political philosophy. Thinkers such as Adam Smith (1723-1790), Thomas Malthus (1766-1834), David Ricardo (1772-1823), James Mill (1773-1836), and John Stuart Mill (1806-1873) extended classical liberalism from politics to political economy. As a consequence, classical political economy developed. These thinkers combined economic and moral philosophy. In contrast to Locke and Hobbes, they lived at the time of the decay of feudalism, the emergence of industrial capitalism, the Enlightenment, and the French Revolution. It is certainly true, as Roy argues, that liberalism did not originate as the ideology of capitalism, but as a broader ideology and philosophy that in the 18th and 19th centuries was turned into the ideology of capitalism. This was not an accident but had to do with the search of the rising bourgeoisie for an ideology guiding its practices and justifying its interests.

A certain mode of production or phase of development of the economy does not result in a single dominant idea system or form of culture. Ideas and culture cannot be read off the mode of production. We can learn from Roy that a mode of production influences but does not determine forms of culture. In relation to a particular mode of production, a variety of cultural forms and cultural contradictions exist. In his Introduction to the Grundrisse, Marx (1857) speaks in this context of "the uneven development of material production relative to e.g. artistic development" (109, emphasis in original) and stresses that in "the case of the arts, it is well known that certain periods of their flowering are out of all proportion to the general development of society, hence also to the material foundation, the skeletal structure as it were, of its organization". This means that culture can but does not necessarily have to flourish in periods of politicaleconomic crises. A crisis of political economy can but does not have to be accompanied by the demise of dominant cultural forms and the emergence of radical cultural novelties.

Communication is an important theme of cultural theory that the next sub-section addresses.

\subsection{Communication}

For Roy (1950a), culture has to do with the ways we experience the world and with the intellectual and emotional world. Communication is a key feature of culture. Wherever there is communication there is culture, and wherever we communicate we produce and reproduce culture. Marx argues that "neither thoughts nor language in themselves form a realm of their own, that they are only manifestations of actual life" (Marx and Engels 1845-1846, 447). And actual life is the "ensemble of the social relations" of individuals, groups, social systems and society (Marx 1845, 7). Culture and communication exist as social relations in which humans produce meaning in the world. These cultural relations exist in connection to society's ensemble of social relations and the ensemble of social relations that humans engage in.

Roy (1940) argues that "[s]ense-perceptions, human experience, gained not in passive contemplation (it cannot be done that way), but in active functioning of the human organism, and having for their source the material world existing objectively outside 
our consciousness, independent of it, is the point of departure of all knowledge" (1940, 252). He writes that

knowledge is derived not in passive contemplation, but in action. 'Philosophers have interpreted the world in various ways, but the real task is to transform it'. Only in the process of transforming the world continuously, does the store of human knowledge endlessly increase; and the knowledge of a given epoch is valuable in so far as it enables man to transform the world, thereby opening a new epoch of progress $(1940,268)$.

Roy states that "[k]nowledge is possible because there is a causal connection between mind and matter" (1947a, 195). Ideas "represent the knowledge of things" (195); they result from mental activities (196); "[k]nowledge results from perception, which is organic reaction to physical contacts" (195). We must add that knowledge is not only formed by humans engaging with physical environments but also with social environments. Humans interact with things when they touch, feel, move, and change them, but things do not talk; they have no language. In the social and societal environment, humans act as languaging, communicating beings so that they interact symbolically with each other, which means that they interpret each other and form meanings of each other.

Living beings react to the world they are part of and that they experience, which is why humans establish a relationship between mind and the world (198). Knowledge is at the same time objective and subjective (198): knowledge is the subjective, mental act of cognising the world (202) that constructs knowledge as an object in the human mind (203). Perception is the process that puts the human subject in relation to the world. Knowing/cognition builds on perception. It is "not a tacit reception or recoding of messages from the external world" (204-205), but an "intelligent reaction" to "messages" that "are stimuli" and sense data (205) gained through experience: "Cognition is an interpretative, denotative, selective, act" (205); "[k]nowledge is a conceptual scheme born out of the insight into the nature of things, gained through critical examination, rational co-ordination and logical deduction of perceptual data" (206).

Roy does not discuss communication in detail, but we can build on his insights. We can apply Roy's ideas to the communication process: in communication, humans establish relations between their minds and thereby between individuals that constitute, produce, and reproduce the social world. They produce and reproduce social relations (Fuchs 2020a). When human beings $A$ and $B$ communicate, then $A$ constructs $B$ as an object in A's mind and B constructs A as an object in B's mind. They sense, perceive, cognise, and experience each other, and react to each other's messages by making meaning of them and creating and externalising symbols as a response. For communicating, humans use their brains as major intellectual means of production, and linguistic and symbolic means of communication through words, grammar, bodily movements, etc. Words are "vehicles for the expression and communication of [...] emotions and ideas" (Roy 1989, 7); "[l]anguages develop to serve the purpose of coordinating disjointed ideas and emotions" (Roy 1989, 7).

Communication is the process through which humans make meaning out of each other. In communication, they mutually reveal ideas, i.e. interpret the world, to each other. Communication is the production of social relations where at least two humans externalise knowledge in symbolic forms, and cognise each other and each other's ideas, such that they interpret the other and their ideas. In communication, humans 
create messages that reach other humans, beginning a perception and cognition process that results in the construction of a mutual knowledge of each other. Communication is the mutual externalisation of knowledge through the human sense organs, and the internalisation of externalised knowledge. Given that, for Roy, cognition is an active process, communication that is based on cognition is also an active production process: communication is the human production and reproduction of social relations (Fuchs 2020a).

The realm of culture, i.e. the production and communication of ideas and meanings, is an important aspect of Roy's theory of society. Roy also gives particular attention to the critique of repressive ideas, namely the ideologies of nationalism and fascism. The next section discusses his analysis of ideology.

\section{Ideology: Liberalism, Capitalism, Nationalism, Fascism}

"An ideology is a system of ideas; in other words, an ideology is the ideal sanction for social and political practices" (Roy 1960/1947, 67). Roy has a general understanding of ideology and differs in this respect from thinkers such as Georg Lukács $(1971,66)$, who sees ideology as reified consciousness that legitimates the interest of the ruling class by trying to "deceive the other classes and to ensure that their class consciousness remains amorphous", or Theodor W. Adorno, who understands ideology as "a consciousness which is objectively necessary and yet at the same time false, as the intertwining of truth and falsehood" (Adorno 1954, 189).

Such critical concepts of ideology stress the illusionary and manufactured character of ideas that make up an ideology and their legitimating role in class structure. Roy speaks of an "ideal sanction for social and political practices", which can in one sense be understood as the legitimation of class relations but is on the other hand formulated in a very general manner, such that, seemingly, for Roy ideology exists in all society and not just, as for Lukács, in class societies.

Leaving aside problems of definitions, Roy in his works analyses the ideological structure of some of the main ideologies of the capitalist age, namely liberalism (Section 5.1), nationalism and fascism (Section 5.2), which resonates with the Frankfurt School's analyses (Section 5.3)

\subsection{The Dialectic of Enlightenment}

The Enlightenment was a movement against the power of the church, the monarch, and the aristocracy. In the 19th century, liberalism started taking on the form of utilitarianism. Thinkers such as David Hume (1711-1776), Jeremy Bentham (1748-1832), James Mill (1773-1836) and John Stuart Mill (1806-1873) influenced utilitarian thought. Roy states that

the liberal doctrine of laisser faire served the purpose of rising Capitalism; and the rule of law came to be the rule of a minority which under the given circumstances had the power to make laws. Liberalism appeared to provide a moral justification of the economic exploitation of man by man and a philosophical sanction for the modern political theories which subordinated the individual to the State (Roy 1989, 330).

Liberal practice has in capitalism undermined the principle of freedom and liberties for all.

Utilitarianism's principle of maximising individual utility and happiness as much as possible and doing so for the greatest number of individuals is for Roy based on a 
"clash of two categorial imperatives" (Roy 1989, 340): individualistic and collectivistic. The one side of this antagonism bears a potential for the advancement of economic individualism in the form of laissez faire-style capitalism that postulates profit maximisation with no government intervention in the economy (342). The other side of the antagonism fetishises collectivism (the happiness of the largest number of people) at the expense of universal rights of all individuals. "The orthodox utilitarian dictum logically justifies suppression of a minority even of forty-nine (because fifty-one is a greater number)" (347). It therefore has the potential to provide "a moral sanction for the various totalitarian cults" (340), to undermine "the equality of men", to advance the "negation of Democracy", and to herald "the advent of dictatorship" (345).

An example of utilitarian logic can be found in debates on the British referendum to leave the European Union. Prime Minister Boris Johnson has repeatedly used utilitarian arguments for justifying the need for a "hard Brexit" without an agreement between the EU and the UK. Johnson identifies "the people" as those who support Brexit. Here are two examples of this demagogic logic of reducing "the people" to those who support Brexit:

Boris Johnson: "What I think people want us to do is to leave the European Union on October 31st" (BBC 2019).

Boris Johnson: "But the way to unite the country, I am afraid, is to get this thing done. [...] What people want to see is a resolution and they want to see us get this thing done. And that's what we're gonna do" (Johnson 2019).

In Britain's 2016 EU referendum, 51.9 percent of the voters opted for Brexit and 48.1 percent against it. This means there is a very large minority that Johnson excludes from his notion of the people. He speaks in favour of the majority and argues for the interest of the largest group of voters while disregarding the interests of the minority. The result is that he advances the political polarisation of the country into two hostile camps.

The basic problem of utilitarianism is that its ethical foundations deny "the permanence of moral values" (Roy 1989, 340). Utilitarian ethics is a "relativist morality" and "ethical nihilism" (341). The result is that utilitarianism has both potentials for the fetishization of individual interests (capitalism's individualism without socialism) and the fetishization of (partial) social interests (collectivism without individuality such as in fascism and Stalinism). It lacks a commitment to universalism (universal rights) and an ethical and political dialectic of individual and social rights.

Roy (1989) argues that positivism and empiricism fetishize scientific knowledge as "a mathematical god" and is a "neo-mysticism" (456; see also 457). Positivism is one aspect of utilitarian liberalism. The logic of calculability supports the accumulation of capital and power because it allows the reduction of society to the instrumental logic of costs and benefits.

There are parallels of Roy's critique of positivism to the analysis advanced by Frankfurt School authors such as Friedrich Pollock, Theodor W. Adorno, Max Horkheimer, Jürgen Habermas, and related thinkers such as Alfred Sohn-Rethel and Georg Lukács.

The Frankfurt School stresses the instrumental character of positivism. Pollock and Adorno, two key members of the Frankfurt School, argue that the rise of mathematics in the social sciences denotes the "convergence of social-scientific methods toward those of the natural sciences" and is "the child of a society that reifies people" (Pollock 
and Adorno 2011, 20). For Horkheimer (2004/1947, 41), "[p]ositivism is philosophical technocracy". Habermas $(1971,67)$ warns that positivism is the "immunization of the sciences against philosophy". Horkheimer and Adorno $(2002 / 1947,25)$ argue that the logic of calculation is the foundation of barbarism: "With the spread of the bourgeois commodity economy the dark horizon of myth is illuminated by the sun of calculating reason, beneath whose icy rays the seeds of the new barbarism are germinating".

Alfred Sohn-Rethel was not a member of the Frankfurt School but was in contact with Adorno, with whom he shared the critique of positivism. Sohn-Rethel (1978) argues that class society's division of labour includes the separation between head and hand. Positivism is the fetishism of mechanistic, quantifying, mathematical reasoning. It is an expression and result of the division of labour.

Georg Lukács inspired the Frankfurt School's analysis of instrumental reason. Lukács (1971) points out that positivism is anti-dialectical: "The methodology of the natural sciences which forms the methodological ideal of every fetishistic science and every kind of Revisionism reject the idea of contradiction and antagonism in its subject matter" $(1971,10)$. Mathematics does not see "the whole system at once" (117). The logic of quantification reduces explanations to basic principles (reductionism) and believes in the exact predictability and calculability of the world (determinism) (117).

In the contemporary social sciences and humanities, digital positivism has emerged as a new form of positivism. It propagates quantitative digital methods, namely big data analytics. The social sciences are thereby re-envisioned as computational social science, a paradigm focused on large datasets, quantification, mathematics, and calculation. Such approaches set out to explain the world based on the analysis of big stocks and flows of data. The problem is that the analysis of big data does not tell us everything that matters. It cannot properly study human motivations, feelings, experiences, norms, morals, values, interpretations, concerns, fears, hopes, etc. It lacks a focus on society's qualities.

Roy $(1953,8)$ argues that there is a contradiction between "the philosophy and the political practice of Liberalism". Capitalism's "cut-throat competition" undermined democracy and resulted in "the stormy rise of Fascism" (9). Roy observed how the failures of liberalism resulted on the one hand in fascism and on the other hand in Stalinism, the fetishization of the collectives of the nation and the working class: "A political system and an economic experiment which subordinate the man of flesh and blood and to an imaginary collective ego, be it the nation or a class, cannot possibly be the suitable means for the attainment of the goal of freedom" (1953, 53-54).

Roy describes and analyses a negative dialectic of the liberal Enlightenment whereby the alienation caused by liberalism let liberalism turn against itself and its own political and moral values, which called forth terror and violence. According to Roy, 19th-century liberalism's utilitarianism, its "law of the jungle" $(1989,428)$, and its atomising individualism called forth "the superman cult" (428), cults of collectivism (427), irrationalism $(428,445)$, "the cult of leadership" (445), and dictatorship (445). The result was "the mystic collectivist cult" (436) of fascism and Stalinism: "In modern Liberalism, the individual became the economic man. [...] But in the context of the capitalist society, the economic man could exist either as a slave or as a slaveowner. That debasement of the individual discredited the liberal democratic doctrine of individual freedom. [...] Ultimately, democracy was destroyed in a fierce clash of totalitarian dictatorships" (Roy 1989, 464), namely fascism and Stalinism. Roy says that humans created a machine that now enslaves them (477) so that the "struggle for freedom [...] ultimately" 
deprives humans of freedom (477). The "creations of man have reduced man to nothingness", which means the "complete subordination of the creator to his creation". Marx (1844) termed this process alienation.

The rise of fascism in Europe was one of the consequences of the Enlightenment's negative dialectic:

In Europe, Fascism represents a reaction to the negative features of the capitalist civilisation, namely, lonesomeness and helplessness of the individual, resulting from his atomisation. These features are accentuated in the period where the progressive potentialities of capitalist economy are exhausted, and monopolist capitalism increases the degree of social insecurity, particularly for the middle and lower classes. In that period, the reaction becomes more violent, and the cultural sanctions of the capitalist civilisation - humanism, rationalism and liberalism - are assaulted (Roy 2006/1945, 22).

Liberal individualism and atomism that expresses itself as the exploitation of wageworkers, the fetishization of private property, capital accumulation, cut-throat competition, and the logic of the accumulation of capital in the economy and of power in the state-system has backfired. The social void it created has been filled with movements for repressive collectivism. Whereas liberal individualism fetishizes the individual at the expense of social freedom, fascism and Stalinism fetishize the collectives of the nation and the state at the expense of individual freedom. Roy $(1989,477)$ argues that in contrast, a radical humanist democracy has to "reconcile individual freedom with social organisation".

In respect to liberalism's self-contradiction, we find parallels between Roy's work and Horkheimer and Adorno's (2002/1947) Dialectic of Enlightenment. Horkheimer and Adorno (2002/1947, xvi) argue that capitalism entails the tendency of the "selfdestruction of enlightenment" (2002/1947, xvi), resulting in "the reversion of enlightened civilization to barbarism" (xix). Capitalism's structures of exploitation and domination turned against liberalism's enlightenment values and in the last instance resulted in Auschwitz: "After the brief interlude of liberalism in which the bourgeois kept one another in check, power is revealing itself as archaic terror in a fascistically rationalized form" (68).

Horkheimer $(2004 / 1947, v)$ points out that in capitalism, Enlightenment tends to nullify itself and transform into its opposite, namely dehumanisation: "Advance in technical facilities for enlightenment is accompanied by a process of dehumanization. Thus progress threatens to nullify the very goal it is supposed to realize - the idea of man". Like Roy, Horkheimer points out that Enlightenment reason emerged as a protest against religion. But in capitalism, reason turned into an instrument of domination and exploitation: "Having given up autonomy, reason has become an instrument. [...] Reason has become completely harnessed to the social process. Its operational value, its role in the domination of men and nature, has been made the sole criterion" (14-15). As a result, "the advance of enlightenment tends at certain points to revert to superstition and paranoia" (21). "Less and less is anything done for its own sake. [...] In the view of formalized reason, an activity is reasonable only if it serves another purpose [...] In other words, the activity is merely a tool, for it derives its meaning only through its connection with other ends" (25). The reduction of reason to a mere instrument neutralises reason and calls forth irrationalism: "At the moment of consummation, reason has become irrational and stultified" (87). Liberalism turns into authoritarianism. "[L]iberalism and authoritarianism tend to interact in a way that helps to vest an ever 
more rigid rational control in the institutions of an irrational world" (49). With the rise of fascism in Europe, "[r]eason [...] ultimately destroyed itself" (Horkheimer 1941, 367). Fascism is an irrational rationality: "The new order of Fascism is Reason revealing itself as unreason" (1941, 387).

Horkheimer and Adorno's argument is that when reason becomes instrumental reason it not only undermines critique but also calls forth irrational forces that advance terroristic systems such as fascism and Stalinism.

"Technological rationality" is Herbert Marcuse's term for what Horkheimer calls "instrumental reason": "Rationality is being transformed from a critical force into one of adjustment and compliance. Autonomy of reason loses its meaning in the same measure as the thoughts, feelings and actions of men are shaped by the technical requirements of the apparatus which they have themselves created" (Marcuse 1998/1941, 49). Marcuse (1988/1965) argues that technological rationality results in rational irrationality. "In the unfolding of capitalist rationality, irrationality becomes reason" (207); "bourgeois reason negates itself in its consummation" (221). Comparably to Horkheimer and Marcuse, Roy (1960/1947, 94) argues that fascism makes "man only an automation, a robot, a small wheel in a gigantic social machinery".

The notions of technological rationality and instrumental reason express several dimensions of capitalism and class society:

\section{- Technology as an instrument of domination:}

Technology is, under the conditions of domination and capitalism, the dominant groups' instrument for the exploitation, control, and surveillance of others.

- Capitalism as social technology:

Capitalism is a type of social technology that reduces humans to the status of workers and consumers and treats them as the instrument, thing, and resource for achieving the goal of capital accumulation. Capitalism is a machine that accumulates capital and produces commodities. It alienates humans from their humanness.

- Ideology as the instrumentalization of consciousness:

In order to reproduce itself, domination requires ideologies that make structures of domination appear natural, without alternative, and good. Such ideologies are for example consumerism, fascism, nationalism, racism, technocracy, technological determinism, neoliberalism, conservatism, militarism, etc. Ideology is a particular form of technological rationality that tries to eliminate critical and dialectical thought in order to instil blind, uncritical faith in ruling ideas into humans. It involves the attempt to reduce human consciousness to the status of machines. Attempts to reify consciousness try to manipulate humans.

- Technological determinism:

Technological determinism is a specific form of ideology that sees technology as being autonomous from society, as the cause of society's changes, problems or advances.

Since 2008, many societies have experienced profound economic, political and ideological crises that together have resulted in a surge of new nationalisms and new authoritarianisms (Fuchs 2018; 2020b). Neoliberal capitalism has experienced a new negative dialectic of the enlightenment. New nationalisms and authoritarianisms are the result of the negative dialectic of neoliberal capitalism and the new imperialism. The commodification of everything, entrepreneurialism, privatisation, deregulation, financialisation, globalisation, deindustrialisation, outsourcing, precarisation and the 
new individualism have backfired, extended and intensified inequalities and crisis tendencies, which have created a fertile ground for new nationalisms, right-wing extremism and new fascism.

\subsection{Nationalism and Fascism}

Roy gives particular attention to the analysis and critique of nationalism and fascism. $\mathrm{He}$ argues that fascism is a militant and terroristic form of capitalism. The bourgeoisie is defending its "waning power with the bloody instruments of Fascist dictatorship" $(1938,6)$; its members throw off "the mask of parliamentarism and wield their dictatorship openly" (38). Roy argues that fascism cannot be reduced to monopoly capitalism because there are forms of monopoly capitalism without a terroristic state. He rather argues that in phases of crisis where fascist movements rise, the capitalist class may find fascist rule a means suited for fostering exploitation and capital accumulation and might therefore support such movements:

Fascism is the most outstanding phenomenon of contemporary history. It has to be explained. It is not enough to call it monopoly capitalism or Hitler Imperialism, whatever that curious phrase might mean. It is not historically correct to identify Fascism with monopoly capitalism. The latter had been in operation in other countries years before Fascism rose in Germany. In those countries, Fascists could not capture power. On the other hand, Italy, where Fascism first succeeded, was an economically backward country. Fascism cannot be explained unless ideological antecedents, the cultural atmosphere, are taken into account. The doctrines with which Fascism swept to power in Germany can be traced in the ideological and cultural history of that country. Fascism also was a result of the dynamics of ideas. Monopoly capitalism, more correctly, capitalism in decay, found that those ideas could serve its purpose very well (Roy 1960/1947, 68).

Roy argues that fascism is different from imperialism. Fascism is not simply a form of imperialism. "Capitalism creates Fascism as the weapon for its last defence, only when it can no longer provide the foundation for Imperialism" (Roy 1943, 60). Roy (1989) points out that the dialectic of the Enlightenment's weakening of reason results "in the storm of emotions running wild" so that it "is easier to sway the people by appeals to their emotions and prejudices than to their reason. [...] Therefore, democracy has everywhere degenerated into demagogy" (468).

The rise of new authoritarianism has been accompanied by a mass of public discourses that are driven by emotions and ideology. Authoritarians often do not believe in anything that can be reasonably explained and proofed, believing only what they want to believe and what fits into their ideology. They often distrust intellectuals, experts, and academia.

During the campaigns for the 2016 Brexit referendum, Michael Gove, then the British Secretary of State for Justice, declared in a television interview that citizens should not and do not trust experts: "I think that people in this country have had enough of experts [...] from organisations with acronyms, saying that they know what is best and get it consistently wrong". ${ }^{2}$ Some speak of the rise of an era of post-truth politics. Posttruth is, however, a rather unspecific and polite term that fails to point out that the questioning of expertise aims at the advancement of lies and far-right ideology. Donald

${ }^{2}$ https://www.youtube.com/watch?v=GGgiGtJk7MA, accessed on 13 September 2019. 
Trump has perfected the practice of declaring any expertise that questions him to be invalid and false. Figure 1 shows an example.

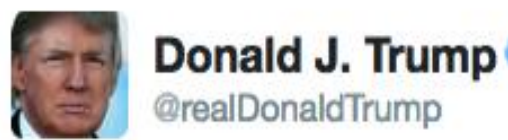

\section{Follow}

The FAKE NEWS media (failing @nytimes, @NBCNews, @ABC, @CBS, @CNN) is not my enemy, it is the enemy of the American People!

\section{RETWEETS LIKES \\ $1: 48$ pm - 17 Feb 2017 \\ $60 \mathrm{~K}$ 는 $33 \mathrm{~K} \quad 102 \mathrm{~K}$}

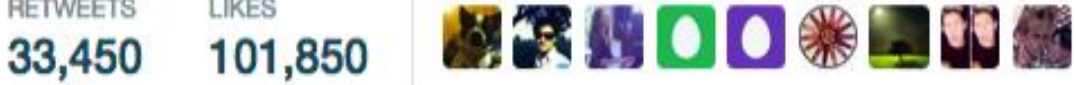

Figure 1: A tweet by Donald Trump about the mainstream media. Source: https://twitter.com/realdonaldtrump/status/832708293516632065

In the tweet shown in Figure 1, Donald Trump characterises certain mainstream media (New York Times, ABC, CBS, CNN, NBC) that often report critically about him as "the fake news media". He thereby identifies himself as the ultimate speaker and representative of the American people and implies that criticism of him is anti-American and directed against Americans. Critics of Trump are presented as "the enemy of the American people". Driven by ideology, irrationality, and emotions, Trump and his followers imagine any criticism and facts not fitting their ideology as inventions. They only believe things that fit into their ideology to be true. Such a demagogic politics aims at radicalising followers and their hatred of identified enemies. It has dangerous, anti-democratic potentials because stoking hatred can easily spill over into violence.

A comparison of critical theories of fascism and authoritarianism shows that there are four elements of right-wing authoritarian ideology, practices, and movements (Fuchs 2018; 2020b): authoritarian leadership, nationalism, the friend/enemy-scheme, and militant patriarchy. Figure 2 visualises the interaction of these four dimensions. Right-wing authoritarianism has an ideological role. By fetishizing the illusionary collective of the nation, right-wing authoritarianism distracts attention from actual class conflicts and class structures. Fascism is a movement that uses terror as its means for advancing capitalism, authoritarianism, nationalism, division, militancy, and patriarchy. 


\section{Right-Wing Authoritarianism (RWA)}

\section{Individual $\Leftrightarrow$ Group $\Leftrightarrow$ Institution $\Leftrightarrow$ Society}

RWA's social role: Deflection of attention from structures of class, capitalism and domination

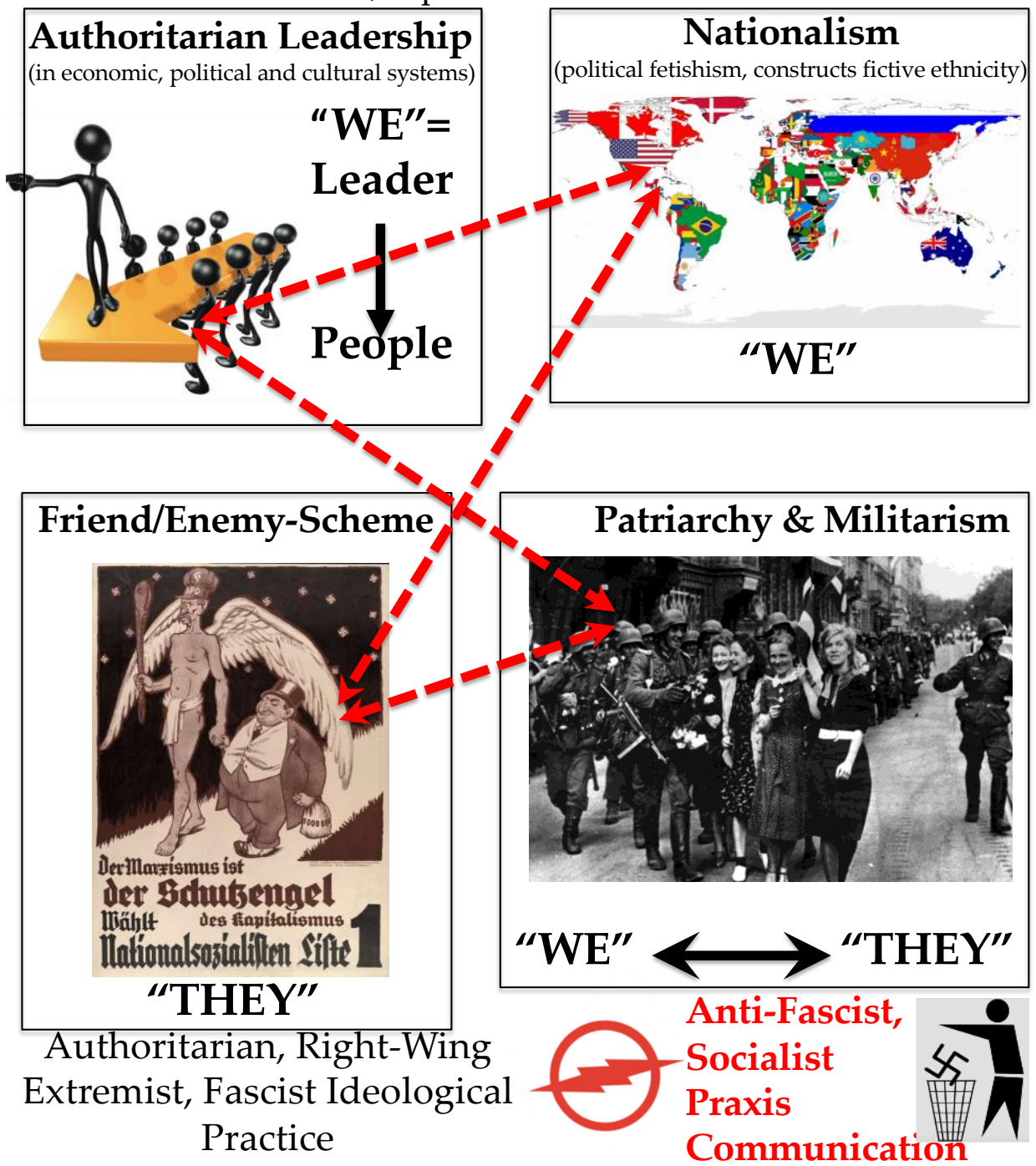

Figure 2: A model of right-wing authoritarianism (Fuchs 2018)

Roy identifies all four features of this model as key dimensions of fascism.

\subsubsection{Authoritarian Leadership}

The "cult of Superman" is a central feature of fascism (Roy 1938, 40): "A Mussolini or Hitler is the personification of the cult of superman" $(1938,53)$. In fascism, "the State is everything and the individual citizen has no right to exist except as pawn of the absolute power which may gamble away his life whenever it pleases" (53).

Authoritarianism uses a "mass psychology dominated by the fear of freedom" (2006/1945, 13); "The fear of freedom created Fascism in Europe" $(2006 / 1945,15)$. The "flight from freedom [...] is the basic social and cultural asset of Fascism" (23). This flight favours the belief in the need for top-down leadership and a Führer. When speaking of the flight from freedom it is evident that Roy (2006/1945) was influenced 
by Erich Fromm's (1969/1941) book Escape from Freedom, published in 1941. Fromm in this book analyses the rise of fascism in Europe: "The giant forces in society and the danger for man's survival have increased [...], and hence man's tendency to escape from freedom" (1969/1941, xiii). Roy does not explicitly acknowledge the connection to Fromm's works. He does not cite or mention Escape from Freedom or Fromm. Fromm himself also became aware of Roy's work. In his book The Sane Society, Fromm (2002/1956, 55) describes Roy's book Reason, Romanticism and Revolution as a "thorough and brilliant analysis". Roy's journal The Radical Humanist published articles by Erich Fromm (Manjapra 2010, 160-161).

\subsubsection{Nationalism}

For Roy, nationalism is an ideology that fetishizes the nation. He therefore speaks of "national jingoism" $(1938,89)$. As a humanist, he politically despised any form of nationalism and argued that nationalism is an element of fascism: "Fascism is nationalism inspired by revivalist ideals" $(1938,40)$; "The essence of nationalism is to place the interests of one's own country above the interests of the world" $(1942,7)$; "There is a spiritual affinity between nationalism and Fascism, the latter being only the most extravagant and aggressive form of the former" $(1942,22-23)$. Roy argues that Marxism is interested in social problems and conflicts while nationalism "has no reference to social problems" (2006/1945, 85). Nationalism demands the sacrifice of the individual to the nation. "The essence of Nationalism, the denial of the very existence of the individual, manifests itself fully in Fascism" (2006/1945, 29). Roy sees nationalism as a metaphysical and irrational ideology that fetishizes the nation:

Nazism and Fascism are condemned as totalitarian because they deny the sovereignty of the individual; they do not give the individual any place in society except as a cog in a vast machinery with a collective ego. [...] Nationalism, by its internal logic, cannot but be totalitarian, because it also postulates a collective ego - the nation. It is a metaphysical concept; yet, human beings, of flesh and blood, must sacrifice everything to make the nation great and glorious. That is the essence of Nationalism. That is, to sacrifice a reality at the altar of a fiction, of an illusion (Roy 1960/1947, 110-111).

There are parallels of Roy's critical theories of nationalism in the works of Rosa Luxemburg and Eric J. Hobsbawm (see Fuchs 2020b). Luxemburg and Hobsbawm, like Roy, stress the illusionary and fictive character of nationalist ideology. Luxemburg $(1976 / 1909,135)$ writes that nationalists see the nation as "a homogeneous social and political entity", remarking that the nation is a "misty veil" concealing the "definite historical content" of class society (135). For Hobsbawm (1983a; 1983b; 1992), nationalism is an invented, which means fabricated and therefore illusionary, tradition that serves the interests of the capitalist class.

Roy $(2006 / 1945,85)$ argues that anti-colonial and anti-imperialist struggles that are nationalist in character are "pseudo-Marxist":

The pseudo-Marxist theory of anti-Imperialism [...] panders to the base sentiment of race hatred, and consequently plays into the hands of social reaction. The doctrine of united anti-Imperialist Front divorces political practice from the context of social conflicts, and making it an expression of racial animosity, helps the upper-class minority to use the people as a pawn in the game of power-politics. 
Providing nationalist power-politics with a pseudo-theoretical foundation, anti-Imperialism helps Nationalism to hide its reactionary social purpose. The misalliance with Nationalism compels Marxism to betray itself $(2006 / 1945,84-85)$.

\subsubsection{The Friend/Enemy-Scheme}

The friend/enemy-scheme is the ideological construction of enemies who are blamed for society's problems. Racism, anti-Semitism, anti-socialism, and anti-Marxism are typical enemy constructions that can be found in fascist ideology. Roy argues that fascism is driven by "fanatical race hatred" $(1938,143)$ and "unscrupulous slander against the opponents, [... the] fanning of race prejudice" $(1938,89)$. Fascism wants to destroy Marxism (93). The "object of Fascism is the destruction of the weak and the triumph of the strong" (133).

\subsubsection{Militarism}

Capitalism is a "violent form of capitalist domination" $(1938,38)$. Fascism implements "arbitrary power and unbounded will" (53): "The Fascist state is the instrument of the dictatorship of the bourgeoisie divested of the deceit of parliamentary democracy" (87). Fascism is a capitalist system that is based on rule of terror. Fascism is "avowedly imperialist" (148), which implies the use of violence and terror for the expansion of capitalist influence.

\subsection{The Frankfurt School on Fascism}

Roy's understanding of fascism resonates with that of the Frankfurt School (Jani 2017). Like Roy, Adorno and Horkheimer identify four dimensions of fascism.

In respect to authoritarian leadership, Adorno argues that the fascist leader presents himself as a great little man, "a person who suggests both omnipotence and the idea that he is just one of the folks" $(1951,142)$. Collective narcissism is a psychological dimension of authoritarianism, because it results in the psychological "enlargement of the subject: by making the leader his ideal he loves himself, as it were, but gets rid of the stains of frustration and discontent which mar his picture of his own empirical self" (Adorno 1951, 140).

In the context of nationalism, Adorno argues that fascists need forms of repressive egalitarianism. Fascist demagogues make use of the logic of repressive egalitarianism: "They emphasize their being different from the outsider but play down such differences within their own group and tend to level out distinctive qualities among themselves with the exception of the hierarchical one" (Adorno 1991, 146). Nationalism is a form of repressive egalitarianism.

Adorno argues that fascists think and act based on the logic of the friend/enemyscheme. The right-wing demagogue "cannot help feeling surrounded by traitors, and so continuously threatens to exterminate them" $(1975,78)$. According to Adorno, identification with the leader and hatred against the out-group allows emotional release $(1975,16-20)$. Such a release of aggression encourages "excess and violence" (1975, 17).

Adorno stresses that fascists see the military as the model for politics and society and soldiers as ideal individuals. They consider war, violence, weapons and guns as the best means of handling conflicts. The "model of the military officer" is "transferred to the realm of politics" $(1975,49)$. Love towards the leader is an "emotional compensation for the cold, self-alienated life of most people" $(1975,37)$. For fascists, survival, toughness, strength and the willingness to fight, lead and compete are moral norms. 
Any "reference to love is almost completely excluded", and the "traditional role of the loving father" is replaced "by the negative one of threatening authority" (Adorno 1991, 137). Horkheimer $(2004 / 1947,14)$ points out that nationalism ends in terror: "The idea of the national community (Volksgemeinschaft) first, first set up as an idol, can eventually only be maintained by terror".

\section{Conclusions}

This article engaged with foundations of M. N. Roy's theory and compared his approach to the Frankfurt School. The first question it asked was: How can M. N. Roy's radical, Marxist humanism inform the critical study of communication, culture, technology, the human being, fascism, and nationalism? We can summarise the main findings in respect to the themes of humanism, technology, culture/communication, and ideology:

\section{Humanism}

- For Roy, humanism is a romantic movement that stresses the transformative capacity of human beings so that they can collectively make their own history.

- For Roy, humanism is a movement for economic, political and cultural democracy, a movement for a participatory democracy that is based on co-operatives and networks of local assemblies.

- Although Roy appreciates Marx's humanism, he argues that there is a fatalistic tendency in Marx's works that sees history as being determined by dialectical economic laws, advances moral relativism, and ignores the importance of human essence for humanism and democracy. Roy's interpretation was not able to take into account some of Marx's important works, especially the Economic and Philosophic Manuscripts, where Marx engages with the notions of human essence as social, creative, self-conscious, productive beings and capitalism/class society as alienation from the human essence in order to ground a humanist-communist philosophy and politics.

- Roy misinterprets Marx's use of Hegelian dialectics. For Marx, dialectics is not simply an objective law but, in society, also operates at the level of the human subject and its social relations, which means that class struggle is an open, dialectical process that has the potential to change society's history. There is a dialectic of the subjective dialectic and the objective dialectic. Class struggle as the making and unmaking of class relations between the exploited and the exploited is the subjective dimension of history. It does not make sense to oppose Marx the humanist and Marx the Hegelian. Marx's dialectic is humanist and his humanism dialectical.

- Engaging and updating the works of humanist socialists such as Roy reminds us that democratic socialism is the strongest weapon against fascism, nationalism, and war.

\section{Technology}

- Roy opposed Gandhi's nationalism and his vision of an ethical capitalism. He argues that Gandhi's politics of a simple life is a form of pessimistic technological determinism, opposed to industry and modern technologies and thereby celebrating poverty and toil, which support capitalist interests.

- Roy stresses the dialectical character of modern technology; that is, its potential to advance slavery and freedom. The actual effects of science and technology depend on human interests, social relations and human practices in these relations. 
- While Gandhi was an anti-modernist, Roy argues for an alternative, socialist-humanist modernity that shapes, creates and uses technologies in manners that abolish toil and advance freedom, democracy and sustainability.

\section{Communication and Culture}

- Roy advances a materialist monist position, which states that the entire world is material.

- Roy sees the brain as humans' key means of production and humans as thinking beings capable of conceptual, creative, anticipatory thought. What needs to be added to Roy's approach is the crucial role of work and production in human existence. Humans are thinking, creative, social, producing, communicating beings. Social production combines the work character of communication and the communicative character of work.

- Roy challenges the assumption that culture and ideas are reducible to the economy.

- Roy's critique of economic determinism during his last, humanist phase of intellectual development was partly also self-criticism of his earlier thought that, based on Plekhanov, saw productive forces and especially geography as determining society.

- Society only exists in and through humans' social relations. Culture as the production and circulation of ideas and meanings takes place within the ensemble of social relations that constitutes the human subject.

- Culture cannot be reduced to political economy; however, it is also not fully independent but grounded in the economy, and at the same time relatively autonomous. Ideas and culture cannot be read off the mode of production. We can learn from Roy that a mode of production influences but does not determine forms of culture.

- In the communication process, humans establish relations between their minds and thereby between individuals that constitute, produce, and reproduce the social world. They produce and reproduce social relations.

\section{Ideology}

- Roy argues that utilitarian liberalism created a negative dialectic of the Enlightenment. Liberal individualism and atomism, expressing itself as the exploitation of wage-workers, the fetishization of private property, capital accumulation, cut-throat competition, and the logic of the accumulation of capital in the economy and of power in the state-system, has backfired. The social void it created has been filled with movements for repressive collectivism, namely fascism and Stalinism. Whereas liberal individualism fetishizes the individual at the expense of social freedom, fascism and Stalinism fetishize the collectives of the nation and the state at the expense of individual freedom.

- Roy identifies four key elements of fascism: authoritarian leadership, nationalism, the friend/enemy-scheme, and militarism. He opposes any form of nationalism because he sees nationalism as the irrational ideological foundation of fascism. Roy stresses that fascism is a violent and terroristic form of capitalism.

The second question that this article asked was: What commonalities are there between Roy's approach and the critical theory of the Frankfurt School? We can summarise the main findings:

- There are strong parallels between Roy's and Herbert Marcuse's analysis of modern technology. Like Roy, Marcuse rejects anti-technological ideology that celebrates 
toil; Marcuse, like Roy, identifies both emancipatory and repressive potentials of modern technology and argues that the actual character and impact of technology depends on broader societal contexts, interests and struggles; Marcuse, like Roy, argues for a socialist modernity where technology is shaped and used in manners that overcome toil and advance freedom, and technology is governed in a democratic manner.

- Roy was critical of positivism. His critique of the fetishism of mathematics and calculation resonates with the approaches of Georg Lukács, Theodor W. Adorno, Max Horkheimer, Friedrich Pollock, Alfred Sohn-Rethel, and Jürgen Habermas, who criticised positivism for lacking an understanding of the qualitative and dialectical character of the world.

- There are parallels between Roy's analysis of how liberalism turned against itself into fascism and Stalinism and Horkheimer/Adorno's Dialectic of Enlightenment. Roy's analysis of fascism is influenced by Erich Fromm's hypothesis of the escape from freedom. Roy, just like the Frankfurt School, sees authoritarian leadership, nationalism, the friend/enemy-scheme, and militarism as key features of fascist ideology and fascist movements.

- Roy, like Horkheimer, Adorno, and Marcuse, argues that Stalinism and fascism are expressions of how the reason of Enlightenment, and liberalism that questioned religious and feudal rule, turned against Enlightenment values. Capitalism individualises and instrumentalizes humans, which undermines social cohesion and especially in crisis times calls forth reactionary forces that fetishize false and imaginary collectives such as the nation, race, and the absolute state.

- Like Marcuse, Horkheimer and Adorno, Roy stresses that authoritarianism and fascism try to treat humans like robots. This is the phenomenon of instrumental reason and technological rationality. Instrumental reason/technological rationality has four dimensions: technology as an instrument of domination, capitalism as social technology, ideology as the instrumentalization of consciousness, and technological determinism.

Both Roy and first-generation Frankfurt School authors such as Max Horkheimer, Theodor W. Adorno, Herbert Marcuse, and Erich Fromm were inspired by Marx and humanist philosophy. The major difference between Roy and the Frankfurt School is that Roy analysed both Western and non-Western society, including India and China, based on Marxist humanism, whereas the Frankfurt School had to limit its analysis to Europe, the United States, and Russia. Marxist humanism is a universal approach that is suited for the analysis of domination, exploitation, ideology, and social struggles in different parts of the world.

Roy's approach shows that the claim that Marxian theory, socialism, and humanism are Western-or Euro-centric and therefore cultural imperialist approaches is erroneous. Whereas Dipesh Chakrabarty $(2008,4)$ argues that Roy was one of the "illustrious members" of the "modern Bengali educated middle classes" that "warmly embraced the themes of rationalism, science, equality, and human rights that the European Enlightenment promulgated", Kris Manjapra (2010) argues in his book about Roy that the latter was not "entrapped in the ideologies attendant to global capital" (xviii), but an "anti-colonial cosmopolitan thinker" (xxi).

Robert Spencer (2017) maintains that post-colonial scholars often tar "all humanisms with the same brush" (121) and "champion difference at the expense of equality" and identity politics over class politics so that to "be a postcolonialist, it seems, is to 
leave one's humanism at the door" (124). Spencer argues for a humanist postcolonialism that is "exercised above all not by crimes against hybridity but by crimes against humanity" (122), that stresses the human "capacity for self-creation" (128) and that speaks "the language of rights [...] animated by the conviction that there are irreducible features of human life" (128) because "it is convinced that only by eradicating the most devastating forms of inhumanity will the human, with all its variability and unpredictableness, come into its own" (129). Humanism means "critical thinking + the ideal of solidarity" (152).

Marxist/socialist humanism allows us to approach the global world as a unity of diverse tendencies. It is an approach that enables the analysis of society in different contexts based on what Vivek Chibber calls the two universalisms, "the universal logic of capital (suitably defined) and social agents' universal interest in their well-being, which impels them to resist capital's expansionary drive" $(2013,291)$. The first universalism foregrounds the accumulation of economic, political and cultural power that in different contexts and on different levels of organisation of global society creates various inequalities. The second universalism calls for solidarity of the world's oppressed and exploited in their struggles for a better world. One of the "recurring themes" in Roy's works and thought is "the reading of underling unity out of apparent difference" (Manjapra 2010, 168).

Both in the West and the Global South, we today are experiencing a surge of new nationalisms and new authoritarianisms. Far-right movements and new nationalisms are the "cicatrices and scars of a democracy [...] that until today has still not lived up to its own concept" (Adorno 2019/1968, 18). They are the result of the negative dialectic of neoliberal capitalism and the new imperialism. The commodification of everything, entrepreneurialism, privatisation, deregulation, financialisation, capitalist globalisation, the new imperialism, deindustrialisation, outsourcing, precarisation and the new individualism have backfired, extending and intensifying inequalities and crisis tendencies, which have created a fertile ground for new nationalisms, right-wing extremism and new fascism.

Three of the main challenges and global problems that humanity faces today are a) the threats of exploding inequalities, accelerating and deepening political-economic crises, fascism, war, violence and genocide posed by the rise of authoritarian capitalism and new nationalisms, b) the threat posed to humans and the environment by natural disasters, climate change and the global environmental crisis, and c) new forms of control and exploitation in the context of capitalist digital technologies, Al-based automation, and algorithmic politics.

The political-economic crisis, the environmental crisis, and the digital crisis have in common that they are crises that threaten fundamental aspects of human life, namely democracy, survival of the species and the planet, and self-fulfilment. They are crises of humanity. The three crises together radicalise the alienation of humans from nature, the economy, political systems, and culture to the point that the interaction of these crises can in the future result in a breakdown of humanity and the livelihood of future generations. We need radical alternatives. As Alderson and Spencer state, "The Left [...] requires a compelling vision of the future as more just, democratic, ecologically sustainable and subjectively satisfying around which it will be possible to construct a viable counter-hegemony" $(2017,218)$. Radical humanism is important today because it advances the counter-vision of a humane society against the dystopias the three crises could result in. Radical humanism can thereby inform social struggles. Radical humanism struggles for the strengthening of the political-economic commons (common control of political and economic organisations), the natural commons (common 
survival in a natural environment that interacts with humans in sustainable manners), and the knowledge and digital commons (knowledge, culture, and digital resources as common goods).

In the age of new nationalisms and authoritarian capitalism, global environmental crises, capitalist crisis, and the digital crisis, socialist-humanist theories such as that of M. N. Roy can inspire struggles for a humanist and socialist society as antidotes to the acceleration and deepening of the three crises. In his Principles of Radical Democracy, Roy $(1953,52-62)$ formulates 22 theses. The final one should be seen as the starting point for contemporary socialist, anti-fascist and anti-nationalist struggles:

Radicalism starts from the dictum that 'man is the measure of everything' (Protagoras) or 'man is the root of mankind' (Marx), and advocates reconstruction of the world as a commonwealth and fraternity of free [...] [humans], by the collective endeavour of spiritually emancipated moral [...] [humans] (Roy 1953, $62)$.

\section{References}

Adorno, Theodor W. 2019/1968. Aspekte des neuen Rechtsradikalismus. Frankfurt am Main: Suhrkamp.

Adorno, Theodor W. 1991. The Culture Industry: Selected Essays on Mass Culture. Edited by J.M. Bernstein. Abingdon: Routledge.

Adorno, Theodor W. 1975. The Psychological Technique of Martin Luther Thomas' Radio Addresses. In Soziologische Schriften II.1, 11-141. Frankfurt am Main: Suhrkamp.

Adorno, Theodor W. 1954. Ideology. In Aspects of Sociology, edited by the Frankfurt Institute for Social Research, 182-205. Boston: Beacon Press.

Adorno, Theodor W. 1951. Freudian Theory and the Pattern of Fascist Propaganda. In The Culture Industry: Selected Essays on Mass Culture, edited by J.M. Bernstein, 132-57. Abingdon: Routledge.

Alderson, David and Robert Spencer, eds. 2017. For Humanism: Explorations in Theory and Politics. London: Pluto Press.

Bastani, Aaron. 2019. Fully Automated Luxury Communism: A Manifesto. London: Verso.

BBC. 2019. BBC News, 6 September 6 2019. Accessed 5 October, 2019. https://www.youtube.com/watch?v=fSygWN-qMfY

Bhattacharya, Subhrajit. 2016. Perspectives on Fascism: M. N. Roy, Horkheimer and Adorno. In M. N. Roy Reader: Essential Writings Volume 3, edited by Bhaskar Sur and R. M. Pal, 1431-1438. Delhi: Aakar Books.

Bloch, Ernst. 2019. Avicenna and the Aristotelean Left. New York: Columbia University Press.

Bose, Nirmal Kumar. 1948. Selections from Gandhi. Ahmedabad: Navajivan Publishing House.

Chakrabarty, Dipesh. 2008. Provincializing Europe: Postcolonial Thought and Historical Difference. Princeton, NJ: Princeton University Press.

Chibber, Vivek. 2013. Postcolonial Theory and the Specter of Capital. London: Verso.

Department for Business, Energy \& Industrial Strategy. 2019. The Grand Challenges. Accessed 7 October, 2019. https://www.gov.uk/government/publications/industrial-strategythe-grand-challenges/industrial-strategy-the-grand-challenges\#artificial-intelligence-anddata (version from 22 May 2019).

Ford, Martin. 2015. Rise of Robots: Technology and the Threat of a Jobless Future. New York: Basic Books.

Fromm, Erich. 2002/1956. The Sane Society. Abingdon: Routledge.

Fromm, Erich. 1969/1941. Escape From Freedom. New York: Avon Books. 
Fuchs, Christian. 2020a. Communication and Capitalism. A Critical Theory. London: University of Westminster Press.

Fuchs, Christian. 2020b. Nationalism on the Internet: Critical Theory and Ideology in the Age of Social Media and Fake News. New York: Routledge.

Fuchs, Christian. 2018. Digital Demagogue: Authoritarian Capitalism in the Age of Trump and Twitter. London: Pluto Press.

Gandhi, Mohandas Karamchand. 1997. "Hind Swaraj" and Other Writings. Edited by Anthony J. Parel. Cambridge: Cambridge University Press.

Gandhi, Mohandas Karamchand. 1983/1948. Autobiography: The Story of My Experiments with Truth. Mineola, NY: Dover Publications.

Habermas, Jürgen. 1971. Knowledge and Human Interest. Boston: Beacon Press.

Hobsbawm, Eric J. 1992. Nations and Nationalism since 1780: Programme, Myth, Reality [second edition]. Cambridge: Cambridge University Press.

Hobsbawm, Eric J. 1983a. Introduction: Inventing Traditions. In The Invention of Tradition, edited by Eric J. Hobsbawm and Terence Ranger, 1-14. Cambridge: Cambridge University Press.

Hobsbawm, Eric J. 1983b. Mass-Producing Traditions: Europe, 1870-1914. In The Invention of Tradition, edited by Eric J. Hobsbawm and Terence Ranger, 263-307. Cambridge: Cambridge University Press.

Horkheimer, Max. 2004/1947. Eclipse of Reason. London: Continuum.

Horkheimer, Max. 1982/1942. The Authoritarian State. In The Essential Frankfurt School Reader, edited by Andrew Arato and Eike Gebhardt, 95-117. New York: Continuum.

Horkheimer, Max. 1941. The End of Reason. Studies in Philosophy and Social Science 9 (3): 366-388.

Horkheimer, Max and Theodor W. Adorno. 2002/1947. Dialectic of Enlightenment: Philosophical Fragments. Stanford, CA: Stanford University Press.

Jani, Disha Karnad. 2017. The Concept of Fascism in Colonial India: M. N. Roy and The Problem of Freedom. Global Histories 3 (2): 121-138.

Johnson, Boris. 2019. Wakefield Speech. 5 September. Accessed 5 October, 2019. https://www.youtube.com/watch?v=G0x1k6p8PJU

Lenin, Vladimir I. 1920. Preliminary Draft Theses on the National and the Colonial Questions. For the Second Congress of the Communist International. In Lenin Collected Works Volume 31, 144-151. Moscow: Progress Publishers.

Lukács, Georg. 1971. History and Class Consciousness. London: Merlin.

Luxemburg, Rosa. 1976/1909. The National Question: Selected Writings. New York: Monthly Review Press.

Luxemburg, Rosa. 1916. The Junius Pamphlet. In Rosa Luxemburg speaks, by Rosa Luxemburg, 371-477. New York: Pathfinder.

Manjapra, Kris. 2010. M. N. Roy: Marxism and Colonial Cosmopolitanism. New Delhi: Routledge.

Marcuse, Herbert. 1998/1941. Some Social Implications of Modern Technology. In Collected Papers of Herbert Marcuse Volume One: Technology, War and Fascism, edited by Douglas Kellner, 41-65. London: Routledge.

Marcuse, Herbert. 1988/1965. Industrialization and Capitalism in the Work of Max Weber. In Herbert Marcuse: Negations: Essays in Critical Theory, 201-226. London: Free Association.

Marx, Karl. 1867. Capital Volume One. London: Penguin.

Marx, Karl. 1857. Grundrisse. London: Penguin.

Marx, Karl. 1852. The Eighteenth Brumaire of Louis Bonaparte. In Marx \& Engels Collected Works (MECW) Volume 1, 99-197. London: Lawrence \& Wishart.

Marx, Karl. 1845. Theses on Feuerbach. In Marx \& Engels Collected Works (MECW) Volume 5, 3-8. London: Lawrence \& Wishart. 
Marx, Karl. 1844. Economic and Philosophic Manuscripts of 1844. In Marx \& Engels Collected Works (MECW) Volume 3, 229-346. London: Lawrence \& Wishart.

Marx, Karl and Friedrich Engels. 1845-1846. The German Ideology. Marx \& Engels Collected Works (MECW) Volume 5. London: Lawrence \& Wishart.

Marx, Karl and Friedrich Engels. 1845. The Holy Family, or Critique of Critical Criticism. Against Bruno Bauer and Company. In Marx \& Engels Collected Works (MECW) Volume 4, 5-211. London: Lawrence \& Wishart.

Pollock, Friedrich and Theodor W. Adorno. 2011. Group Experiment and Other Writings. Cambridge, MA: Harvard University Press.

Ray, Sibnarayan. 2016a. M. N. Roy: A Biographical Chronology. In M. N. Roy Reader: Essential Writings Volume 3, edited by Bhaskar Sur and R. M. Pal, 1439-1462. Delhi: Aakar Books.

Ray, Sibnarayan. 2016b. M. N. Roy in Communist Opposition. In M. N. Roy Reader: Essential Writings Volume 3, edited by Bhaskar Sur and R. M. Pal, 1289-1302. Delhi: Aakar Books.

Roy, M. N. 2006/1945. Problem of Freedom. Calcutta: Renaissance Publishers.

Roy, M. N. 1989. Reason, Romanticism and Revolution. Delhi: Ajanta Publications.

Roy, M. N. 1968. Men I Met. Bombay: Lalvani Publishing House.

Roy, M. N. 1960/1947. Beyond Communism. Delhi: Ajanta Books.

Roy, M. N. 1953. New Humanism: A Manifesto. Calcutta: Renaissance Publishers. Second edition.

Roy, M. N. 1950a. Cultural Requisites of Freedom. In Modern Age \& India, edited by Atindranath Bose, 177-192. Calcutta: Left Book Club.

Roy, M. N. 1950b. Fragments of a Prisoner's Diary Volume Two: India's Message. Calcutta: Renaissance Publishers.

Roy, M. N. 1949. A Politics for Our Time. In M. N. Roy Reader: Essential Writings Volume 2, edited by Bhaskar Sur and R. M. Pal, 927-941. Delhi: Aakar Books.

Roy, M. N. 1947a. Science and Philosophy. Calcutta: Renaissance Publishers.

Roy, M. N. 1947b. Since the Communist Manifesto. In M. N. Roy Reader: Essential Writings Volume 2, edited by Bhaskar Sur and R. M. Pal, 890-913. Delhi: Aakar Books.

Roy, M. N. 1946/1930. Revolution and Counter-Revolution in China. Calcutta: Renaissance Publishers.

Roy, M. N. 1943. The Communist International. Bombay: Radical Democratic Party Publications

Roy, M. N. 1942. Nationalism: An Antiquated Cult. Bombay: Radical Democratic Party

Roy, M. N. 1940. Materialism: An Outline of the History of Scientific Thought. Dehra Dun: Renaissance Publication.

Roy, M. N. 1938. Fascism: Its Philosophy, Professions and Practice. Calcutta: D.M. Library.

Roy, M. N. 1929a. Meine Vebrechen: Offener Brief an die Mitglieder der Kommunistischen Internationale. Gegen den Strom 37: 9-11.

Roy, M. N. 1929b. My Crime. In M. N. Roy Reader: Essential Writings Volume 1, edited by Bhaskar Sur and R. M. Pal, 188-195. Delhi: Aakar Books.

Roy, M. N. 1923. India's Problem and its Solution. Charleston: Nabu Press. Reprint.

Roy, M. N. 1922. India in Transition. Geneva: Edition de la Librairie J.B. Target.

Roy, M. N. 1920. Supplementary Theses on the National and Colonial Question. Presented at the Fourth Session of the Second Congress of the Communist International, July 25, 1920. Accessed 7 October, 2019. https://www.marxists.org/history/international/comintern/2nd-congress/ch04.htm

Roy, Samaren. 1997. M. N. Roy: A Political Biography. London: Sangam Books.

Roy, Samaren. 1987. M. N. Roy and Mahatma Gandhi. Columbia, MO: South Asia Books.

Sohn-Rethel, Alfred. 1978. Intellectual and Manual Labour: A Critique of Epistemology. London: Macmillan. 
Spencer, Robert. 2017. Postcolonialism is a Humanism. In For Humanism: Explorations in Theory and Politics, edited by David Alderson and Robert Spencer, 120-162. London: Pluto Press.

Srnicek, Nick and Alex Williams. 2015. Inventing the Future: Postcapitalism and a World Without Work. London: Verso.

Tarkunde, Vithal Mahaedo. 1982. Introduction to the Author. In New Orientation, by M. N. Roy, v-x. Delhi: Ajanta Publications.

Tendulkar, Dinanath Gopal. 1953. Mahatma: Life of Mohandas Karamchand Gandhi. Vol. VI: 1945-1947. New Delhi: Publications Division.

Williams, Alex and Nick Srnicek. 2013. \#Accelerate: Manifesto for An Accelerationist Politics. Accessed 7 October, 2019. https://syntheticedifice.files.wordpress.com/2013/06/accelerate.pdf

Williams, Raymond. 2003/1974. Television: Technology and Cultural Form. London: Routledge.

\section{About the Author}

Christian Fuchs

Christian Fuchs is a critical theorist and the co-editor of tripleC: Communication, Capitalism \& Critique. http://fuchs.uti.at, http://www.triple-c.at, @fuchschristian 